\title{
ARQUEOLOGÍA, ARQUITECTURA E HISTORIA DEL ARTE ALTOMEDIEVAL: GÓMEZ-MORENO Y EL RETO DE LA INTERDISCIPLINARIEDAD EN EL CENTRO DE ESTUDIOS HISTÓRICOS*
}

\author{
ARCHAEOLOGY, ARCHITECTURE AND HISTORY OF HIGH \\ MEDIEVAL ART: GÓMEZ-MORENO AND THE CHALLENGE OF \\ INTERDISCIPLINARITY IN THE CENTRO DE ESTUDIOS HISTÓRICOS
}

\author{
Francisco J. Moreno MarTín ** \\ Universidad Complutense
}

\begin{abstract}
RESUMEN. Transcurrido un siglo desde la publicación de Iglesias Mozárabes (1919), obra fundamental para el conocimiento y la ordenación del arte altomedieval hispano, este artículo analiza de forma integral sus bases metodológicas e ideológicas a partir de la revisión de la figura de Gómez-Moreno en el Centro de Estudios Históricos. Nuestro planteamiento permite insertar este trabajo dentro de una perspectiva regeneracionista fundamentada, por un lado, en la renovación del método de análisis de los edificios históricos a partir de una incipiente interdisciplinaridad con enfoques procedentes de la arqueología y, por el otro, en la identificación de las raíces orientales de la cultura española desde la Prehistoria hasta la Edad Media.
\end{abstract}

PALABRAS CLAVE: Metodología, historiografía, arqueología, historia del arte, arquitectura.

ABSTRACT. It has been a century since the publication of the book Iglesias Mozárabes (1919), the most important study around the High Medieval Hispanic Architecture. Our article summarizes its methodological basis, considering both the ideological perspective of its author and the institution that supported it: GómezMoreno and the Centro de Estudios Históricos. Our main conclusions allow us to frame this book in the general renewal experienced by Spanish science during the first two decades of the $20^{\text {th }}$ century. Gómez-Moreno should be considered the first researcher to apply multidisciplinary approaches to the study of historical Architecture. In addition, the book presents the cultural activity of the so-called «Mozarabs» as another step in the formation of the Spanish identity deeply influenced by Eastern civilizations.

KEYWORDS: Methodology, Historiography, Archaeology, History of Art, Architecture.

* Este trabajo ha sido realizado en el marco del proyecto de investigación MINECO-Ministerio de Economía y Competitividad «Arqueología e Interdisciplinariedad: una investigación arqueológica-histórica sobre las relaciones interdisciplinares en la Historia de la Arqueología española (siglos XIX y xx)» (HAR2016-80271-P, IP M. Díaz-Andreu) subvencionado por la AEI/FEDER, UE.

\footnotetext{
** Correspondencia a / Correspondence to: Francisco J. Moreno Martín, Dpto. Historia del Arte. UCM - franjmor@ucm.es - http://orcid.org/00000001-8317-9381.

Cómo citar / How to cite: Moreno Martín, Francisco J. (2020), "Arqueología, Arquitectura e Historia del Arte altomedieval: Gómez-Moreno y el reto de la interdisciplinariedad en el Centro de Estudios Históricos", Veleia, 37, 95-119. (https://doi.org/10.1387/veleia.20972).
}

Recibido: 29 junio 2019; aceptado: 11 noviembre 2019.

ISSN 0213-2095 - elSSN 2444-3565 / (C) 2020 UPV/EHU 


\section{INTRODUCCIÓN}

Por muchas razones Manuel Gómez-Moreno (1870-1970) debe considerase una de las figuras capitales de la Historia del Arte y de la Arqueología en España (Gaya Nuño 1975a, 225). Entre sus obras sobresale un trabajo excepcional e irrepetible que, con el título de Iglesias Mozárabes. Arte espanol de los siglos $I X$ a XI, fue publicado en 1919. La arquitectura de estos le inspiró para encontrar un ideal que, por imperfecto, individualista, anticlásico y revolucionario, ponía rostro a una espańolidad huérfana tras la debacle del 98 (Gómez-Moreno 1970b, 321, Varela 1999, 106). La invención de este estilo respondía a la necesidad de construir un arte opuesto a lo europeo (Gómez-Moreno $1913,116 ; 1919,1)$ y de sublimar a un colectivo que trascendiera las fronteras de nuestra alta Edad Media. No es, en modo alguno, un capricho, sino que en él subyace una actitud vital y la madurez de un método en el estudio de la arquitectura. Este modelo de pensamiento se asienta cómodamente en los ideales krausistas (Varela 1999, 89), y en él se une lo mozárabe con un arte español «flexible, original, fresco, individual», vinculado a una Castilla democrática y libre (Gómez-Moreno 1919).

Transcurridos cien años, muchos de sus datos y parte de las teorías propuestas mantienen su vigencia para el estudio de la arquitectura de la alta Edad Media hispana (Gutiérrez 1970, 96; Utrero 2005 , 29). Este trabajo tratará de analizar cómo ambos aspectos — pensamiento y método- se coadyuvaron en la cristalización de los objetivos marcados, a la vez que sirvieron para fijar en la memoria historiográfica la figura de Gómez-Moreno como pionero, al mismo tiempo, de la Historia del Arte y de la Arqueología españolas.

Fue una figura de referencia en la arqueología practicada en su tiempo, una arqueología paradójicamente ajena a muchos de los vocales de la Junta Superior de Excavaciones y Antigüedades, como Benlliure, Lampérez o Tormo (Díaz-Andreu 2004, CXXXV) o mejor, como dice Schnapp $(2002,135)$, de la arqueología que no es patrimonio de los arqueólogos y no requiere de excavación (Caballero Zoreda 1996). Es cierto que Gómez-Moreno apenas excavó, lo que le aproxima más a una generación de historiadores del arte preocupados por establecer vínculos entre arquitectura medieval y nacionalismo, a la que pertenecen, entre otros, Puig i Cadafalch o Focillon (Dacosta 2004, 65). De hecho, ha sido dentro de este ámbito donde su labor ha alcanzado mayor reconocimiento (Gómez-Moreno Calera 2016, 94-95). Para Gaya Nuño (1975a, 221) fue, junto a Cossío, «la flor y nata» de la historiografía del siglo xx. Ruíz de la Peña le considera pionero en equiparar el edificio al documento, mientras que para García Cuetos $(2011,132)$ sus análisis directos de los monumentos representan la base de la disciplina.

Gómez-Moreno, junto con otros investigadores del momento —incluido Mélida, quien, por diversos motivos, puede ser su «némesis» (Díaz-Andreu 2004, LV) - representa tanto el eclecticismo metodológico de una época como el espíritu colaborativo del Centro de Estudios Históricos (CEH) donde coexistían Arqueología e Historia del Arte (Bellón Ruiz 2015, 74). El discurso histórico, para él, debía construirse combinando la proyección cultural de los objetos artísticos con su estratigrafía y las tradiciones que las alumbraron, sin olvidar los datos textuales convenientemente decantados (Gómez-Moreno 1928 (1974), 14-15), modelo que transmitirá a sus discípulos (Camps Cazorla 1935, 8). Es justo recordar, no obstante, que en su obra también habita la contradicción que acompaña a algunos trabajos desarrollados en el $\mathrm{CEH}$ puesto que, si bien contribuyeron a situar la ciencia histórica en estándares europeos, no lo es menos que lo hicieron a partir de un profundo $-\mathrm{y}$, en ocasiones irracional - sentimiento de nacionalismo cultural (Varela 1999, 155). En una España donde los ecos del naufragio del 98 resonaban todavía con estridencia, era urgente reconstruir la identidad española y ahí estaba Gómez-Moreno para rastrearla en los albores de la Edad Media. 
Lo variado de sus intereses, sumado a su longevidad, dificulta la realización de una biografía intelectual completa en perspectiva interdisciplinar (Bellón Ruiz 2015, 142). En todo caso, aunque con errores, resulta fundamental la escrita por su hija María Elena Gómez-Moreno (1995) y la más reciente de Gómez-Moreno Calera (2016), el estudio de Bellón para la reedición de Adam y la prehistoria (2015) y la introducción de Lorenzo \& Pérez (2017) a su epistolario durante la realización del catálogo monumental de Zamora. Pese a su complementariedad, estos trabajos no resuelven algunas cuestiones que, como la trabazón epistemológica y vital en sus aportaciones a la cultura material altomedieval hispana, abordaremos a lo largo de este artículo.

Su labor, reivindicada por arqueólogos e historiadores del arte, resulta básica para la profesionalización de ambas disciplinas (Caballero Zoreda 2010, 1, Rodríguez Mediano 2002, 71, Salvatierra Cuenca 2013, 186) y nos sugiere la existencia de numerosas intersecciones metodológicas. Sería admirado por todas las profesiones relacionadas con la historia y el patrimonio (Vega 2016, 79), puesto que, como dice Gaya fue «fotógrafo, dibujante, epigrafista, numísmata y trepador a todos los riscos de España» (Gaya Nuño 1970, 165). Como arqueólogo en su momento, familiares y discípulos - entre ellos Camps, Mergelina o Mata Carriazo- lo reconocieron como uno de los más importantes del siglo xx (Contreras 1970, 212, Gómez-Moreno 1995, 172 y 358, Gutiérrez 1970), quizás favorecido por la posición central que ocupaba el Centro de Estudios Históricos (Díaz-Andreu 2004, XCVI, CIII; Salvatierra Cuenca 2013, 202). Sin embargo, su perfil de arqueólogo no es unánimemente aceptado en la actualidad. Sin ánimo de ser exhaustivos, no se cuestiona entre historiadores del arte medieval (Gómez-Moreno Calera 2016, 89), entre los estudiosos del mundo antiguo (Bellón Ruiz 2010, 120, 2015, 12, Gozalbes Cravioto 2005), la tardoantigüedad (Caballero Zoreda \& Murillo 2006, 78, González 1993) o la historia de la ciencia (López Sánchez 2006), y hay consenso al situarlo como uno de los pioneros del uso de la fotografía en arqueología (González Reyero 2007, 221). Desde una parte de la Prehistoria se le considera más «arqueólogo de gabinete» (Díaz-Andreu 1997, 408), siendo este un ámbito en el que contó con cierta antipatía, especialmente en el círculo del catalán Bosch Gimpera, donde se reconocía a Mélida como "el primer arqueólogo español» (Díaz-Andreu 2004, XCVI, CIII). En suma, su aceptación como arqueólogo está fuertemente condicionada por la perspectiva disciplinar, cronológica (e incluso historiográfica) desde la que se aborde. Intentaremos demostrar que, en lo que atañe al estudio del patrimonio construido altomedieval, Gómez-Moreno dio un paso trascendental al dotar sus investigaciones con enfoques y técnicas tomadas de la arqueología.

\section{Sus AÑos de JUVENTUd}

\subsection{Granada. Formación}

Manuel Gómez-Moreno Martínez no venía de una familia cualquiera. Su padre, Manuel Gómez-Moreno González (1834-1918) fue un personaje fundamental en la investigación y gestión del patrimonio granadino durante el XIX, al tiempo que referente indiscutible en la formación de su hijo (Olmos Romera 2012, 27). Gracias al trabajo de Moya (2004) podemos reconfigurar hoy una trayectoria profesional a caballo entre la práctica artística, la enseńanza y la política cultural. El tándem formado por los Gómez-Moreno («el viejo» y «el mozo») constituye uno de los más valiosos ejemplos hacia la profesionalización científica del estudio y cuidado del patrimonio monumental (Bellón Ruiz 2015, 21). La infancia del pequeño Manuel en Granada y en Roma (1878-1880) estuvo marcada por las antigüedades, las excursiones científicas y la práctica del dibujo (GómezMoreno 1970a, 11). El vínculo con esta ciudad permite entender su trayectoria. El paisaje monu- 
mental que lo vio crecer hizo germinar su amor por el arte andalusí. La polémica búsqueda de la ciudad de Iliberri — sede del primer concilio hispano- junto con su experiencia italiana, acrecentó su interés por el primitivo arte cristiano. Su casa en el Albaicín acogió a eruditos y anticuarios locales que le condujeron irremisiblemente hacia la Arqueología y la Historia del Arte. La pulsión por el arte andalusí — pese a ciertos sinsabores - se reflejó en las primeras obras en colaboración con su mentor (Gómez-Moreno (González) 1892; Gómez-Moreno 1907) y dejó profunda huella en su concepción del arte medieval hispánico. Al hablar de sinsabores nos referimos a la polémica gestión de La Alhambra que enfrentó a los Gómez-Moreno y otros eruditos locales con Rafael y Mariano Contreras, directores del monumento entre 1847 y 1907, criticados por su deficiente actuación arqueológica y conservadora (Rodríguez Domingo 1997, 346).
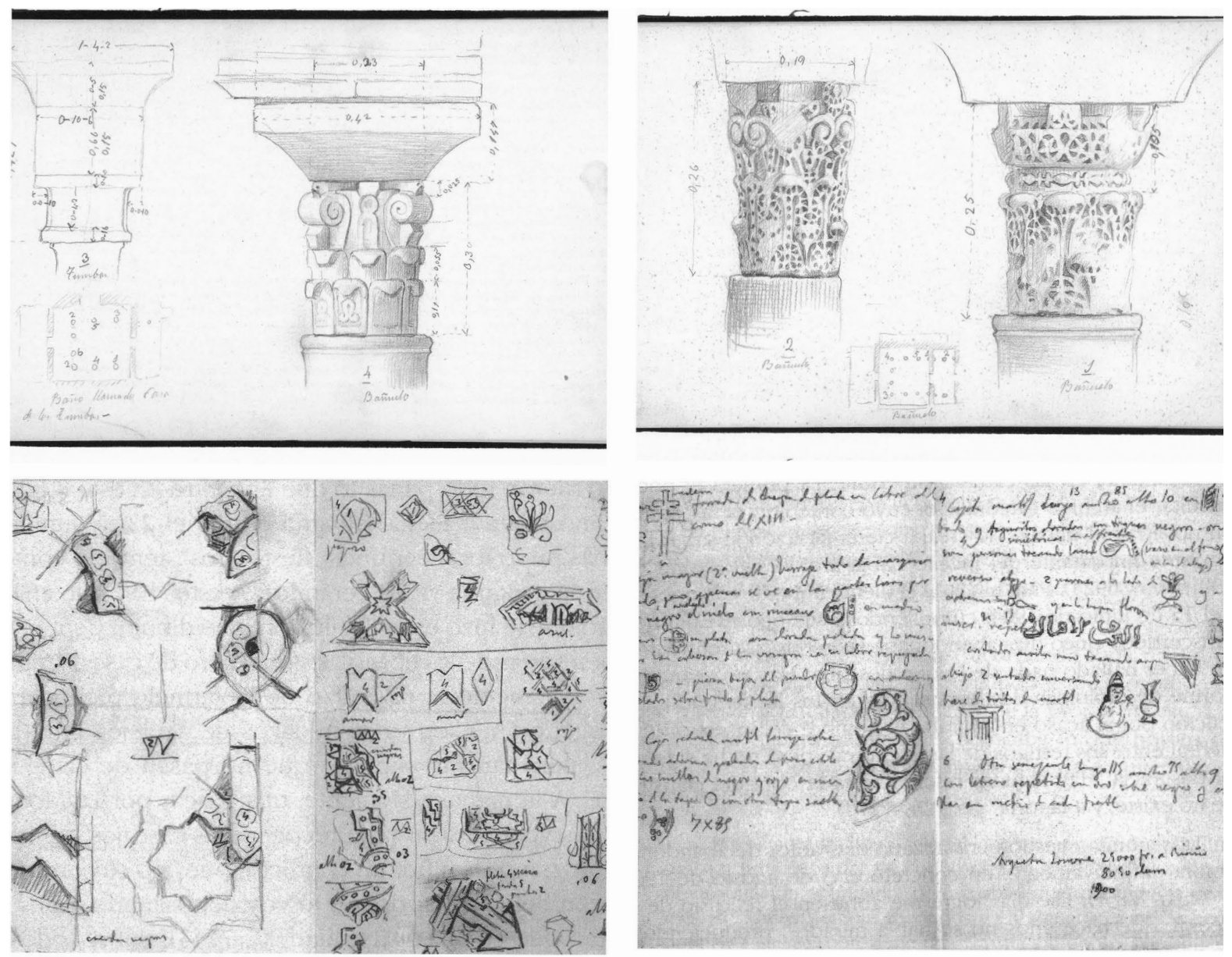

Figura 1. Notas de campo de trabajos de Gómez-Moreno "el viejo» (arriba) y de su hijo (abajo). Fuente: (Lorenzo \& Pérez Martín 2017, 51, Moya 2004, 65).

Manuel padre no era estrictamente arqueólogo, aunque practicó la arqueología tal y como era entendida en su tiempo. Fue profesor del Colegio del Sacromonte, presidió la Comisión Provincial 
de Monumentos y fue correspondiente de las de la Historia y de la de Bellas Artes al tiempo que iniciador del Museo Arqueológico Provincial y del Centro Artístico y Literario de Granada (Bellón Ruiz 2015, 33). Documentó las excavaciones del cortijo de la Daragoleja y en Atarfe, donde la cerámica hallada le hizo identificarla con la Hadira-Elvira islámica (Gómez-Moreno 1907, 20, 52, Mederos Martín 2018, 111, Moya 2004, Salvatierra Cuenca 2013, 197), allanando la ubicación de Iliberri en el Albaicín. Ciertos hábitos de trabajo fueron asimilados por su hijo, como la obsesión por dibujar y medir todo, por documentarlo en cuartillas que facilitaban las posteriores interpretaciones (Gómez-Moreno 1970b, 345). De hecho, años más tarde, uno de sus discípulos recordaba que don Manuel era persona de «muchísimas notas manuscritas tomadas en sus excursiones y visitas en una letra menuda y clara. Ilustradas con dibujos muy bien hechos de todo género de obras de arte, desde planos de monumentos arquitectónicos hasta firmas de cuadros, en pequeños trozos de papel, a veces diminutos y siempre dentro de unas carterillas de una simple cuartilla doblada» (Angulo 1970, 229) (figura 1).

Junto a su padre experimentó una «formación no reglada» de la arqueología de su tiempo. Aprendió paleografía para manejar las fuentes escritas en la recomposición del relato histórico, siéndole esta capacitación de gran ayuda para abordar años más tarde el estudio de las pizarras visigodas (Gómez-Moreno 1966, 17). Asumió la necesidad de tener en cuenta el registro cerámico, a cumplir con la obligación de levantar planos de las estructuras halladas (figura 2) y a clasificar restos óseos (Gómez-Moreno 1905, 93; 1949b, 409). Por último, junto a su padre se inició en el uso de la fotografía (Bellón Ruiz 2015, 38). No encontramos, en cambio, ni rastro de la estratigrafía practicada a finales del xix por geólogos y paleontólogos evolucionistas, pese a que en el bachillerato en Granada tuvo contacto con el darwinismo a través de las obras del naturalista Rafael García Álvarez (Gómez-Moreno 1970a, 13, Mederos Martín 2018, 111, Otero 2017, 31). Tal vez actuó como contrapeso frente a una posible influencia evolucionista la relación con Manuel de Góngora y Martínez, catedrático de Historia Universal en Granada, firme defensor del creacionismo (Beltrán Fortes 2011, 28) y compañero de su padre en la Comisión de Monumentos (Moya 2004, 45).

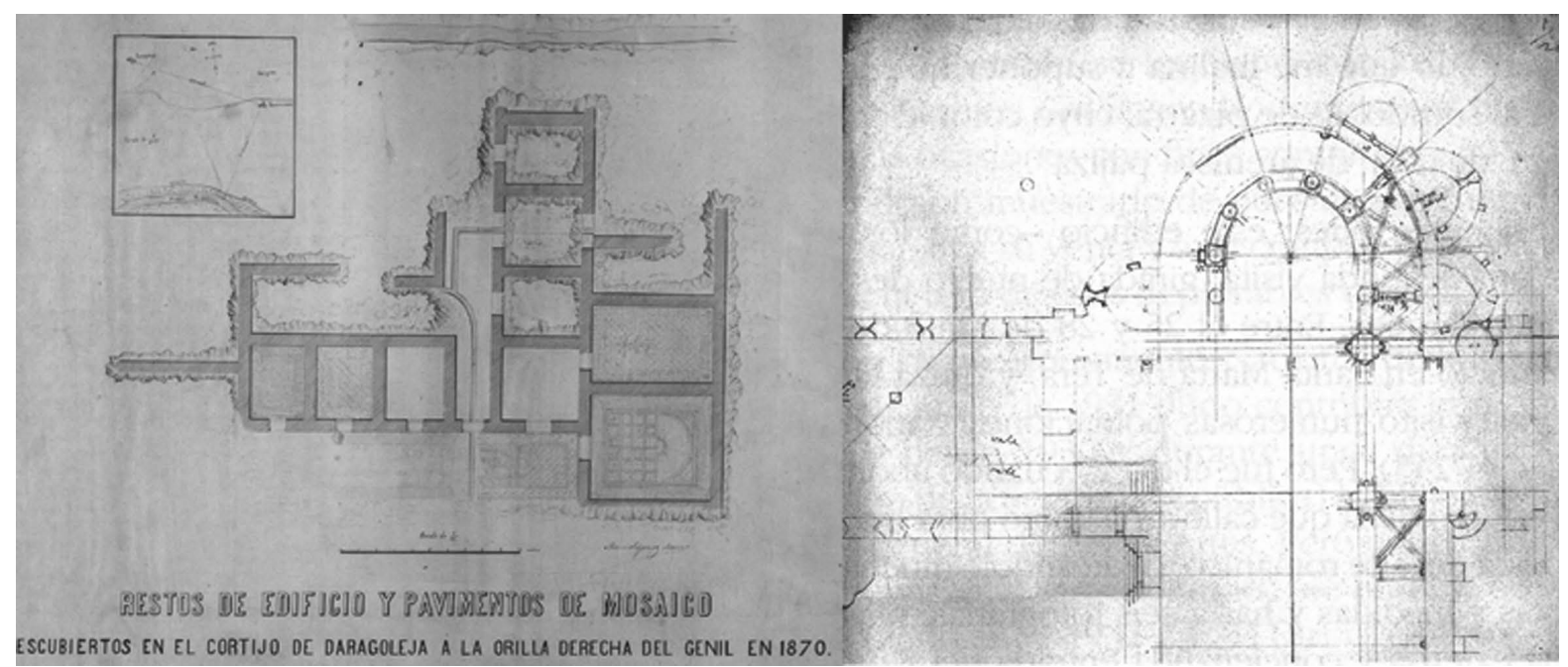

Figura 2. Plano del yacimiento de Daragoleja, de la mano de Gómez-Moreno padre (Moya 2004) y planimetría del monasterio de Moreruela por Gómez-Moreno hijo (Lorenzo \& Pérez Martín 2017: 57). 
De sus estudios universitarios conviene destacar las lecciones de árabe tomadas con el ultracatólico Francisco Javier Simonet, una relación que le valió corregir y editar, a la muerte de este, su Historia de los Mozárabes (Gómez-Moreno 1970a, 15). Estas lecciones dieron jugosos frutos en su posterior vida profesional, entre ellos la publicación de inscripciones inéditas granadinas en sus Monumentos Arquitectónicos (Gómez-Moreno 1907) o la identificación del bote de Alhaquem en la catedral de Zamora (Lorenzo \& Pérez Martín 2017, 275).

Siendo todavía joven comenzó a labrarse una carrera profesional en el ámbito del patrimonio local. En 1887 alcanzó el puesto de secretario del Centro Artístico y Literario, donde redactaba las crónicas de las excursiones al tiempo que daba sus primeros pasos en la práctica fotográfica (Mederos Martín 2018, 116). Con 25 años fue nombrado profesor de Arqueología sagrada y Dibujo en el Seminario del Sacro Monte (Gómez-Moreno 1970a, 19).

Aunque por su carácter local esta formación pueda considerarse propia de un anticuario de provincias (Rodríguez Mediano 2002, 73), conviene subrayar su vertiente práctica, que adquiere todavía más valor al confrontarla con los programas de estudio en la Escuela Superior de Diplomática donde se formaban los arqueólogos en la capital desde el año 1856 y destinada a la formación del Cuerpo de Bibliotecarios, Archiveros y Anticuarios (Peiró Martín \& Pasamar Alzuria 1989-90, 11-12). La Arqueología allí impartida (vinculada a las Bellas Artes) estaba plegada a la construcción material del discurso nacional (Hernández Hernández \& De Frutos González 1997, 135) de la mano de la diplomática y la archivística necesarias para la ordenación de los documentos eclesiásticos que sobrevivieron al proceso desamortizador (Almagro 2004, 59). Hasta 1884, la Arqueología no alcanzó su independencia, cuando pasó a ocuparse del estudio de las obras de arte e industria por «su antigüedad», concepto manejado con enorme laxitud (Peiró Martín \& Pasamar Alzuria 1989-90, 15). Ni rastro de la estratigrafía en boga en la Geología y la Paleontología estimuladas por la teoría evolucionista en las Ciencias Naturales. Tampoco la Prehistoria despertaba ningún interés en sus programas porque, pese a su antigüedad, los objetos prehistóricos carecían del valor artístico concedido a los monumentos (Peiró Martín \& Pasamar Alzuria 1989-90, 21). En conclusión, la formación obtenida por los arqueólogos en la Escuela no era, en lo teórico, sustancialmente distinta a la obtenida por Gómez-Moreno, mientras este podía presumir de una preparación práctica que no se ofertaba en Madrid. Cabe recordar que Mélida, alumno de la promoción de 1873-74 (Díaz-Andreu 2004, 24), no tuvo contacto con la arqueología hasta su ingreso con 18 años. Una vez en ella apenas recibió formación práctica (Casado Rigalt 2006, 29, 38).

\subsection{Madrid. Exploraciones}

1898, año clave para el devenir político-cultural de España, también fue el del desembarco del joven granadino en Madrid, postulando a una cátedra de Historia del Arte en la Escuela Central de Artes y Oficios (Gómez-Moreno 1970a, 21), plaza que fue también firmada por Mélida y Lampérez, aunque finalmente fue desconvocada (Mederos Martín 2018, 120). Podemos suponer que su erudición y escaso bagaje técnico no desentonarían entre los colegas capitalinos al estar la disciplina de la Historia, como otras muchas entonces, desactualizada por su aislamiento historiográfico (Hübner 1888,7$)$ y participar de los males que impedían el avance de la ciencia nacional: escasez de recursos y fuerte oposición de los sectores ultramontanos a corrientes progresistas (Otero 2017, 15). Entre los más destacados defensores del avance del conocimiento científico como fórmula ineludible para la evolución del país se encontraban los miembros de la Institución Libre de Ense- 
ñanza. Gracias a ciertos contactos madrileños, Gómez-Moreno entabló con algunos integrantes de este grupo una fructífera relación profesional y personal.

Recuperar la confianza en la ciencia era la clave del proyecto forjado en el seno de la ILE, fundada en 1876 por Giner de los Ríos. Sus postulados racionalistas (krausistas), positivistas y evolucionistas eran la reacción frente a las corrientes ultracatólicas que controlaban la educación del país (López Sánchez 2006, 208, Otero 2017, 37). Como parte de la corriente regeneracionista, aspiraba fortalecer el rigor en los procedimientos, apostar por la instrucción pública y lograr la independencia de las enseñanzas superiores (López-Ocón 1999, 145, Otero 2017, 51-53). La preocupación del círculo institucionista por la Historia y la Cultura venía, sin embargo, de más atrás. Ambos factores habían concitado los esfuerzos de la ILE en la reactivación de los estudios en Historia del Arte por Giner y Cossío, desde su parcela de pedagogos, y por Juan Facundo Riaño, desde una perspectiva de renovación investigadora (Varela 1999, 233, Guerrero 2016, 34). En la práctica esto supuso la recuperación de la enseñanza de técnicas artísticas tradicionales y el conocimiento directo de la obra de arte (Arnaldo 2016, 267).

A la altura de 1900, el bagaje experiencial que Gómez-Moreno podía ofrecer al proyecto regeneracionista coincidía con muchos de los postulados de la ILE: trabajo de campo, conocimiento del arte español, rigor en los procedimientos y un incipiente manejo de la fotografía. Estas virtudes fueron decisivas para recabar el apoyo de Juan Facundo Riaño, quien tenía sobradas referencias del joven Manuel por la estrecha relación mantenida desde hacía años con la familia, a las que pudo sumar algunos informes favorables enviados en 1897 por Hübner a —en sus propias palabras_ ciertos «amigos en Madrid» (Bellón Ruiz 2015, 37). Riaño, con el apoyo del Ministerio de Instrucción Pública, le encargaría la realización de los Catálogos Monumentales de España (Gómez-Moreno 1970a, 25, Bellón Ruiz 2015, 19). El encargo, como se había estipulado para todos los catálogos, iba dirigido a una única persona para preservar la unidad de criterio (Bellón Ruiz 2015, 64), lo que despertó algunas quejas emitidas por las Academias de Bellas Artes y la Historia que dieron al traste con este plan abriéndose la tarea a otros investigadores (Bellón Ruiz 2015, 61, Díaz-Andreu 2004, 61). Se perseguía con estos catálogos abandonar el diletantismo a favor de la precisión para elaborar un riguroso inventario sobre el que basar las políticas de protección y difusión del patrimonio nacional. Gómez-Moreno constataría este amateurismo durante la elaboración de los tomos correspondientes a Ávila, León y Zamora. A propósito de esta última provincia escribía "he leído casi todo lo de eruditos locales, que es deficientísimo y reducido a unos cuantos lugares comunes» (Lorenzo \& Pérez Martín 2017, 37). Por otro lado, este contacto con la Castilla de principios de siglo, le aproximó al sentimiento noventayochista tan presente en la literatura del momento (Olmos Romera 2012, 32).

Fue una década, la primera del siglo xx, marcada por el sacrificio en la realización de los catálogos y la inestabilidad profesional. A cambio, Gómez-Moreno consolidó definitivamente su método de trabajo y creó una red de contactos que le llevaría a colaborar codo a codo junto a quienes, desde el regeneracionismo liberal, iban a construir el entramado institucional que modernizó la ciencia española: la Junta para la Ampliación de Estudios (López Sánchez 2006, 21).

La política de la JAE, vigilada con recelo desde el tradicionalismo católico, se fundamentó en dos ámbitos: la concesión de pensiones para la formación de los científicos españoles en el extranjero y la creación de centros de investigación en los que consolidar los métodos implementados tras su regreso. Bajo esta segunda premisa vio la luz el Instituto Nacional de Ciencias Físico-Naturales en cuyo seno arrancó la Comisión de Investigaciones Paleontológicas y Prehistóricas (Otero 2017, 61). Resulta pertinente mencionar este hecho porque, como consecuencia del mismo, el debate en torno al evolucionismo se restringió al ámbito de las Ciencias Naturales y, con él, las aportaciones 
desde la Geología, la Paleontología y la Prehistoria, disciplinas dinamizadoras del método estratigráfico (Bellón Ruiz 2015, 51).

La discusión histórica irrumpió en la JAE cuando los tradicionalistas invocaron la necesidad de mantener el vínculo entre ciencia e Iglesia (Otero 2017, 38). Esta reacción anti-moderna obligó a derribar el edificio ideológico levantado por historiadores como Menéndez Pelayo, pues constituía una auténtica rémora para el progreso científico (Varela 1999, 51). Nació así, en 1910, el Centro de Estudios Históricos (CEH), en cuya primera memoria se marcan, entre otros objetivos, la publicación de fuentes documentales y la organización de excavaciones y exploraciones para el estudio de los monumentos (Castillejo 1998, 47). En un primer momento, José Castillejo, secretario de la JAE y auténtico sostenedor del CEH, se apoyó en una red de contactos personales surgidos en torno a la Revista de Aragón y Cultura Española, entre los cuales se encontraban Menéndez Pidal, Altamira, Tormo y Ribera (López Sánchez 2006, 24). Aunque López Sánchez (2006, 24) sitúa a Gómez-Moreno en el núcleo fundacional de Cultura Española, y por tanto del CEH, Bellón $(2015,80)$ minimiza su papel, puesto que se encontraba en Granada en el momento gestacional del proyecto. Sea como fuere, Manuel recibió con enorme alegría la propuesta de integrarse en el centro como responsable de la sección de «Arte Medieval» y así se lo transmite a su esposa («sería cosa muy de mi gusto, acaso más que una cátedra», en Castillejo 1998, 30). Con el visto bueno de Giner y Cossío se dispuso a estudiar una serie de edificios altomedievales que había conocido durante la realización de los catálogos (Gómez-Moreno 1995, 214, Castillejo 1998, 35) cuyo análisis completaría mediante excursiones junto a sus alumnos (Castillejo 1998, 38), encajando su proyecto dentro de las coordenadas regeneracionistas del centro y sus mentores, quienes sugerían la realización de trabajos centrados en la temprana Reconquista (López Sánchez 2006, 52). Este habría de ser el primer paso de un estudio más amplio que abarcaría todo el arte hispano anterior a la llegada del románico (Castillejo 1998, 333).

En 1914, su sección pasó a denominarse de «Arqueología y Arte Medieval Español» (Cabañas Bravo 2007, 144), aunque en el centro era "Arqueología» a secas para distinguirla de la de «Arte» dirigida por Tormo. La introducción nominal del término «arqueología», por aquel entonces consolidada dentro de los trabajos de Prehistoria, no significó un cambio de rumbo en sus líneas investigadoras. Fiel a sus postulados fundacionales, la Prehistoria permanecía todavía al margen del CEH. Valga como prueba que, de las 96 publicaciones de Gómez-Moreno entre 1914 y 1935, solo tres tratan sobre la Protohistoria, y ninguna sobre la Prehistoria (Gómez-Moreno Calera 2016, 178-186).

De esta organización podemos extraer algunas interesantes conclusiones de carácter metodológico. El personal del centro trabajaban como «abejas» en una «colmena» donde fluía la comunicación (Moreno Villa 1939 (2006), 73) pero las «celdas» de Arqueología y Arte estaban separadas por intereses y métodos. A la primera le correspondía estudiar los períodos pre y pleno medievales a partir de exploraciones arquitectónicas, mientras el grupo de Tormo se dedicaba a las artes figurativas desde la baja Edad Media en adelante aplicando el método filológico (Cabańas Bravo 2007, 145, Arciniega García 2014, 32, 57). En 1910 el propio Tormo había establecido la rigurosa separación entre ambas disciplinas marcando la experiencia estética como frontera infranqueable (Arciniega García 2014, 20). La fundación de la revista Archivo Español de Arte y Arqueología en 1925 mantuvo esta división. Quizá sea relevante apuntar que Juan Antonio Gaya Nuño consideraba un error incluir en el título la Arqueología, "ya por aquellos años segregada de lo puramente artístico» (Gaya Nuño 1975b, 231). Esta visión retrospectiva tiene que ver con el despegue en los años 20 de una Arqueología prehistórica que, voluntariamente, se había distanciado de los estudios artísticos. 


\subsection{El arte de enseñar a ver}

La entrada de Gómez-Moreno en el CEH le permitiría experimentar la moderna metodología docente implantada por Giner y Cossío. Aunque conocía la enseñanza en contacto con los monumentos, jamás antes había podido vincularla tan claramente a la investigación. Los recursos del centro permitían la reducción en el número de alumnos y contar con medios de proyección en el aula (Gómez-Moreno 1995, 287). Don Manuel organizaba las sesiones teóricas como tertulias en las que se interrumpía y discutía (Gómez-Moreno 1995, 218). El Marqués de Lozoya (Contreras 1970, 210), asistente a sus clases en 1917, recuerda la profundidad de los datos técnicos e históricos y la brillantez expositiva del maestro trazando la evolución de la arquitectura islámica desde oriente a occidente. Con todo, su principal apuesta por la renovación docente fueron las excursiones. La primera fue a la iglesia altomedieval de San Pedro de la Mata junto a Torres Balbás y Allende Salazar (Gómez-Moreno 1995, 219), obra clave para la comprensión de la arquitectura prerrománica peninsular (Utrero 2005, 521).

Resulta paradójico que, en esos mismos años de investigación y magisterio, él mismo tuviera que adoptar el rol de estudiante al tener que preparar el doctorado para acceder a una cátedra en la Universidad Central como paso ineludible antes de ser nombrado director de la sección de Arqueología (Gómez-Moreno 1995, 247). Este proceso — glosado detalladamente por Gómez-Moreno $(1995,254)$ y Bellón Ruiz $(2015,94)$ — no estuvo exento de problemas administrativos e intrigas personales y se puede recomponer a través de su epistolario (Castillejo 1998, 473). El resultado final fue la toma de posesión de la cátedra de Arqueología Arábiga que ocupó hasta su jubilación voluntaria en 1935, molesto por el traslado a la nueva Facultad de la Ciudad Universitaria y el aumento en el número de alumnos por clase (Gómez-Moreno 1995, 466).

De este meteórico ascenso interesa subrayar algunos aspectos. El primero es que su memoria para la obtención del doctorado fue un trabajo breve — como solían ser todos los del momentoque con el título De Arqueología Mozárabe pasa por ser un anticipo de su posterior Iglesias Mozárabes (Gómez-Moreno 1913). Por otro lado, de la renuncia a optar a la cátedra de Historia del Arte que le había ofrecido Tormo (Bellón Ruiz 2015, 58) se desprende que tenía esperanza en que se dotara, como finalmente ocurrió, otra que representara mejor sus intereses científicos desarrollados en el CEH.

Maestro exigente en el esfuerzo y aprendizaje por «ver» en los monumentos, cuando revisamos la nómina de sus discípulos más importantes resulta evidente su vocación interdisciplinar (Olmos Romera 2012, 36). Uno de los primeros fue Torres Balbás sobre el que comentaba a su esposa durante la primera excursión a Toledo en 1910 que: «creo que me será de provecho, pero el otro [Allende Salazar] dudo de encarrilarlo (...) no creo que vea ni llegue a ver cosa en los edificios» (Castillejo 1998, 126). A esa misma generación pertenece Francisco Nebot quien, como Torres Balbás, era arquitecto de formación, y aprendió junto a don Manuel Arqueología e Historia del Arte (Vílchez Vílchez 1999, 39). Torres Balbás se convirtió en figura referente del arte andalusí (Gozalbes Cravioto 2005, 244). Logró materializar los anhelos conservacionistas y arqueológicos de su maestro - y del padre de este - al ser nombrado director de La Alhambra (Salvatierra Cuenca 2013, 204). Nebot, recomendado por Josep Pijoan por su capacidad como dibujante (Castillejo 1998, 100), llegó a ser director de la Escuela de Arquitectura de Barcelona (Bellón Ruiz $2015,85)$.

A estos les siguieron, entre otros, Camps Cazorla, Ricardo de Orueta, Moreno Villa, Cayetano de Mergelina o Juan de Mata Carriazo. El primero fue, según Gaya (1975, 244), su discípulo predilecto y quien mejor se adaptó al perfil investigador de Gómez-Moreno (Salvatierra Cuenca 2013, 
205). Camps, en su dedicatoria al maestro del libro El Arte Románico en España dice «nada de esto es nuevo. Es luz de otro cerebro más poderoso», reconociendo el magisterio y dependencia de Gómez-Moreno en los estudios sobre el mozárabe y el románico (Camps Cazorla 1935, 21). Amplió el modelo explicativo de Gómez-Moreno hacia el arte visigodo creando un esquema aceptado por toda la historiografía peninsular (Fernandes 2003, 208). En cuanto a Ricardo de Orueta, cuando en 1911 le acompañó en su viaje a Mérida, logró interesarle por las ruinas «cuando antes solo tenía ojos para la escultura» (Castillejo 1998, 433) hasta tal punto que, en sus análisis posteriores sobre la escultura altomedieval española, apreciamos enfoques que rebasan ampliamente el análisis visual histórico-artístico (Orueta 2015, 64). El tercer discípulo de nuestra lista, José Moreno Villa, llegó a Gómez-Moreno a través de Giner en 1911. Su labor fue la de dibujar los elementos ornamentales en códices mozárabes por su buena mano y conocimientos paleográficos (Huergo 2001, 63, Moreno Villa 1939 (2006), 71). No debió ser esta una relación fácil, puesto que sus testimonios reflejan dificultades de convivencia, aunque también de reconocimiento mutuo. Moreno Villa tildó a don Manuel de «estúpido, aunque sepa más que todos los Archivos de España» (Huergo 2001, 63) sin restar méritos a su capacidad e intuición en la catalogación de pintura, superiores en ocasiones a las de Tormo (Huergo 2001, 612). Moreno, con formación alemana, efervescente artista de vanguardia y poeta (Cabañas Bravo 1995, 381) , respiraba la cultura de su tiempo de manera muy distinta a la de su jefe (Castillejo 1998, 329) y recuerda con dureza el tiempo en el CEH por no poder dedicar tiempo a la poesía (Moreno Villa 1939 (2006), 74). Al contrario, Gómez-Moreno (1995, 240) dijo de él que «llega de Alemania y no encuentra árbol donde ahorcarse». Pese a todo, cuando Moreno, exiliado en México, definió el arte tequitqui como fórmula híbrida entre lo indígena y lo colonial (Huergo 2001, 50) parece subyacer una base conceptual cercana a lo «mozárabe» y lo «morisco».

Cayetano de Mergelina sería el «más arqueólogo de sus discípulos» (Gómez-Moreno 1995, 350). En su compañía identificó la rebelde Bobastro en el yacimiento malagueño de Las Mesas de Villaverde (Gómez-Moreno 1995, 353), excavándolo en los años 20 (Salvatierra Cuenca 2013, 206). Por último, Juan de Mata Carriazo se interesaría en la cultura antigua y protohistórica, en 1927 colaboró con Mergelina en la excavación de la cámara sepulcral ibérica de Toya (Jaén) y se hizo cargo del yacimiento de Itálica (Salvatierra Cuenca 2013, 202). En 1958 colmó las «expectativas tartesias» de su maestro con la excavación de El Carambolo a propósito de cuyo descubrimiento se evidencia la familiaridad de un ya anciano Gómez-Moreno con la estratigrafía arqueológica y los materiales cerámicos (Bellón Ruiz 2015, 10, 143).

\section{Arquitectura y Arqueología en la trayectoria de Gómez-Moreno}

\subsection{Hacia la aplicación del método arqueológico para el estudio de los monumentos}

Granada, Madrid, la tradición finisecular y el comienzo de un esperanzador ciclo para la investigación española marcan el itinerario formativo y profesional de don Manuel. Como hemos subrayado, en su perfil convergen las disciplinas básicas para el estudio del patrimonio monumental, mucho antes de que estas separaran su caminos al construir su propia especialización metodológica (Moreno Martín 2014).

Desde mediados del siglo xIx Arqueología (más bien anticuariado) y Arquitectura habían transitado de la mano. Formaron una de las secciones de las Comisiones de Monumentos (Hernández Hernández \& De Frutos González 1997, 143), con un marcado interés por los edificios medievales 
(Rivière Gómez 1997, 135) y, excepcionalmente, por yacimientos arqueológicos de este período, como Medina Azahara, Guarrazar o Hadira Elvira. Las excavaciones en el primero de estos sitios, Medina Azahara, habían sido iniciadas en 1853 (Rivière Gómez 1997, 137) y en 1911 las dirigía el arquitecto Velázquez Bosco (Salvatierra Cuenca 2013, 204). En cuanto a Guarrazar, los trabajos fueron excepcionales por la particular situación en la que se vio envuelto el hallazgo del tesoro visigodo (Balmaseda 1997, 209) y por su importancia en términos políticos e ideológicos (Moreno Martín 2017). La investigación judicial auspició una excavación minuciosa por capas de cuatro a seis pulgadas de espesor acompañada de una concienzuda documentación (Cortadella 1997, 278). Finalmente, aunque de carácter más local, hay que recordar los trabajos en Hadira Elvira desarrollados por Gómez-Moreno "padre» en Atarfe (Moya 2004, 359).

Superados los enfoques biográficos ilustrados, la investigación arquitectónica de los monumentos espańoles en el XIX (ver un exhaustivo balance en Lampérez y Romea 1908, 14-20), se centró en visiones románticas en las que, como Recuerdos y Bellezas de España (1839-1865) y España Artística y Monumental (1842-1850), los textos se acompañaban de bellas láminas de escaso valor técnico y nulo arqueológico. Estas carencias fueron parcialmente subsanadas con la serie de $\mathrm{Monu}$ mentos Arquitectónicos de España (1856-1882), donde a los estudios de arqueólogos como Manuel de Assas, José Amador de los Ríos y Serrano (Salvatierra Cuenca 2013, 198) se le suman plantas, alzados y secciones, una documentación valiosa que, en ocasiones, fue corregida por el propio Gómez-Moreno, como es el caso de los altares en la iglesia mozárabe de Escalada (Gómez-Moreno $1919,160)$.

En 1908 apareció la Historia de la Arquitectura Cristiana Española de Vicente Lampérez. Al reivindicar el carácter fundamental del análisis del edificio en sus dimensiones planimétrica, estructural y decorativa, la obra se acompaña de abundante documentación gráfica en la que no faltan «interpretaciones» sobre el estado original de muchos ejemplos (restauraciones en estilo «virtuales» similares a algunas de las desarrolladas por él mismo). Desde una perspectiva profundamente positivista, clasifica y ordena los edificios y sus partes (Lampérez y Romea 1908, 23). El libro no estuvo exento de errores y Gaya lo tilda de «esfuerzo indudablemente grande pero bien lejos de la perfección tanto en la filiación de muchos monumentos como en lo defectuoso de no pocos planos» (Gaya Nuño 1975a, 219). Sin embargo, tuvo la virtud de despertar el interés por la arquitectura altomedieval española en el extranjero (Gómez-Moreno 1995, 218), aunque no creemos, como sí lo hace Azuar $(2016,77)$, que deba ser considerado estímulo para que Gómez-Moreno acometiera el estudio del ciclo constructivo mozárabe.

Este panorama nos permite asegurar que el método de análisis aplicado por Gómez-Moreno en sus estudios de edilicia histórica resulta trascendente por la suma de enfoques tradicionales (textual, formal y tecnológico) y otros procedentes de su experiencia arqueológica. Para él, la arquitectura es reflejo del espíritu de la sociedad que la genera y su primer síntoma de civilización. Evoluciona con ella, pero siempre en relación con su función y los recursos técnicos disponibles (Gómez-Moreno 1907, 2; 1949a, 20; 1970b, 323). Ya en su estudio de los dólmenes de Antequera (Gómez-Moreno 1905) implementa algunas de las herramientas para llegar a estas conclusiones. El análisis arranca del examen directo de las estructuras, que acompaña de planimetrías y fotografías realizadas por él mismo. El texto incluye la caracterización geológica e identificación de canteras, descripción del aparejo, de las herramientas de talla mediante el análisis de las huellas en el material pétreo (lo que le lleva a aproximarse al ambiente técnico de producción) y recogida y caracterización de materiales cerámicos en superficie. Organiza con las tumbas una tipología evolutiva de supuestos orígenes orientales que logra insertar en un marco histórico coherente con sus indagaciones. Una cultura, la tartesia, evolucionada a partir de contactos orientales (Gómez-Moreno 1905, 126). 
Avanzado el tiempo, para la elaboración de los catálogos monumentales desarrolló, además de estas herramientas, loables intentos por secuenciar las distintas fases en algunos edificios. Cuando habla de las iglesias románicas en Zamora dice estar desenredando "diversos períodos de construcción», que le llevaron a «andar casi por el aire (...) por tejados» (Lorenzo \& Pérez Martín 2017, 105,142). En San Pedro de la Nave, documenta los desplomes y las consiguientes reparaciones románicas (Lorenzo \& Pérez Martín 2017, 177). Como viaja solo, necesita «llevar consigo» los monumentos en cientos de notas, dibujos, planos y fotografías que le permiten corregir lo ya publicado (Gómez-Moreno 1910). Efectúa descripciones extremadamente detalladas, especialmente en «sitios arqueológicos» hasta entonces inéditos (Gómez-Moreno 1904, 148).

Una de las claves en sus análisis arquitectónicos son los tipos o sistemas de comprensión formados por modelos de edificios o elementos singulares de la fábrica (Caballero Zoreda 2010, 3). Estas series parten del concepto artístico de original-copia, base del sistema "gomezmoreniano" que le obliga a manejar enormes repertorios formales y técnicos de las tradiciones locales y foráneas para establecer analogías que, sobre una línea histórica, se convierten en secuencias evolutivas (Bellón Ruiz 2015, 238). Esta dinámica original-recepción-copia realiza frecuentemente el mismo movimiento (excursión) desde oriente a occidente. A este concepto le suma la idea de continuidad de los procesos histórico-culturales y el reflejo material del espíritu colectivo y la territorialidad (Dacosta 2004, 347, Bellón Ruiz 2010, 122). Con independencia de su valor estético, se agrupan y se secuencian de forma relativa para ayudar a desbrozar un panorama edilicio donde no abundan referencias textuales, asociando los elementos seriados con períodos culturales: prerromano, romano, visigodo, árabe, mozárabe, asturiano y románico (Gutiérrez 1970, 97).

Encontramos sistemas compuestos por planimetrías (dólmenes, castros fortificados), materiales (tapial, morteros), aparejos (sillería, mampostería) y ornamentaciones. Su intento por tipologizar la decoración de lazo, frustrado por su complejidad geométrica y matemática, le condujo a atesorar ejemplos durante su vida (Gómez-Moreno 1995, 286). "Estoy haciendo una especie de cuadros y derivaciones (...) tengo más de cincuenta tipos» escribía a su padre en 1911 (Castillejo 1998, 781).

Sin embargo, sería la Excursión a través del arco de herradura (1906) el estudio tipológico que mayores réditos le proporcionaría, pese a sus evidentes debilidades (Caballero Zoreda 1977). Habituado a su presencia en territorio andalusí, se reencuentra con ellos en sus andanzas leonesas y zamoranas, donde solían considerarse «obra árabe» (Lorenzo \& Pérez Martín 2017, 121). Convencido de poder trazar su evolución formal a partir de diferentes contextos y estímulos sociales, busca sus orígenes en época pre-islámica con modificaciones que documenta hasta el siglo XI. El punto clave en su interpretación es la consideración de ciertos arcos cordobeses, tradicionalmente islámicos, como de época visigoda con influencia bizantina, estableciendo tres referentes básicos: el de la puerta de Sevilla en la muralla, el de la fachada de San Esteban y los de entibo de la arquería de la primera fase de la mezquita, para él restos de la basílica anterior (Gómez-Moreno 1906, 14-16). Sus rasgos específicos serían: 1) prolongación de la curva en un tercio del radio bajo la línea de imposta y, 2) convergencia del despiece de las dovelas en el centro de la circunferencia. La aplicación de este modelo le permite identificar, como visigodos, edificios como San Juan de Baños, San Pedro de la Nave o Santa Comba de Bande.

Por contra, el modelo andalusí de arco de herradura se impone en las ampliaciones de la aljama cordobesa con evidentes variaciones: 1) la curva de cierre se prolonga la mitad del radio de la circunferencia; 2) el despiece de las dovelas arranca desde el centro de la línea de imposta; 3) se acompaña de alfiz y 4), a partir de época califal, se eleva el trasdós (figura 3). Su presencia, a uno y otro lado de la frontera, avala la identificación de edificios posteriores al siglo IX, entre ellos un reducido grupo de iglesias mozárabes (Gómez-Moreno 1906, 26). El establecimiento de variables «crono-ti- 
pológicas» fue una herramienta de investigación admitida inmediatamente por la historiografía del momento (Lampérez y Romea 1908, 146; Mélida 1913, 32) para convertirse en marca identitaria, de la escuela surgida en torno al investigador granadino. Bastaría con asomarse, entre otros, a los plegados «tubulares» en la escultura altomedieval de Orueta $(2015,64)$ o a la "excursión» por los modillones de lóbulos de Torres Balbás (1936).

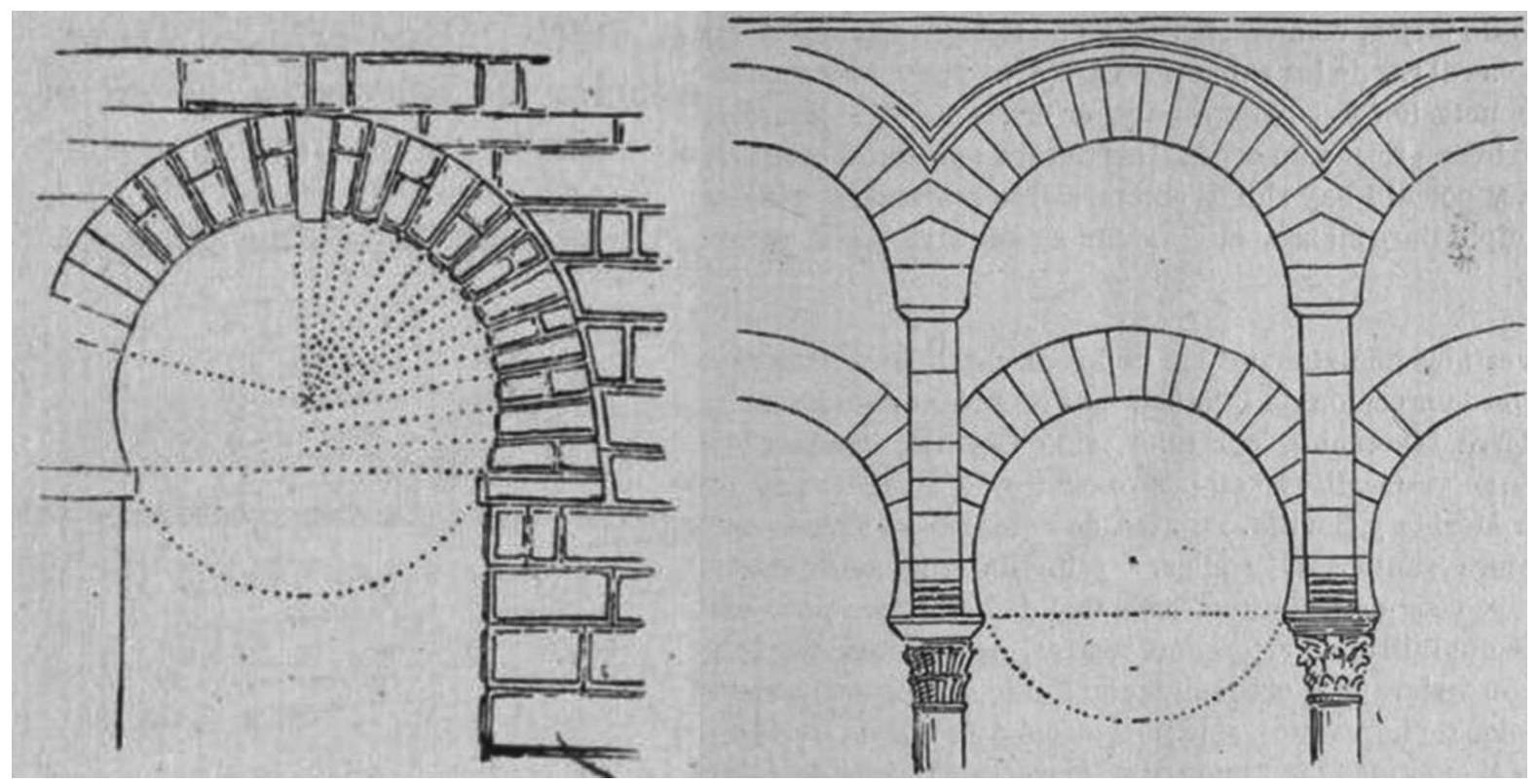

Figura 3. Arco de herradura visigodo frente al modelo islámico, según Gómez-Moreno (1906).

Al catalogar un arco de herradura —ornamental o estructural — como visigodo, andalusí o mozárabe, se arrastra con él al edificio que lo incluye. Es decir, se trata de datar el elemento para "poder datar» con él, y, al hacerlo, sumar a la serie otros indicadores cronológicos: bóvedas gallonadas, modillones, capiteles, frisos, etc. La seguridad que proporciona este sistema le permite distinguir las etapas constructivas dentro de un mismo monumento (Gómez-Moreno 1913, 112). Aunque no podemos considerarla estrictamente una tipología arqueológica, por carecer de base estratigráfica (Schnapp 2002, 138), su implementación constituye un hito fundamental en el estudio de la arquitectura medieval hispana que incorporó, con menos éxito, series tipológicas al estudio del románico, como el repertorio de motivos decorativos de origen hispano sobre dibujos de su propia hija (Gómez-Moreno 1934, 141). Tal vez queriendo reivindicar su base arqueológica, él mismo tituló De Arqueología Mozárabe a su memoria de doctorado el año 1913, un trabajo construido a partir de la identificación de la tipología de los arcos de herradura.

Hasta entonces — como para muchos en ese momento- las "cosas de arqueología» habían pertenecido a épocas anteriores a la Edad Media (Hübner 1888, Peiró Martín \& Pasamar Alzuria 1989-90). El propio Gómez-Moreno, decía a principios de siglo que las "cosas arqueológicas», como despoblados, castros, berracos o cerámica protohistórica, le consolaban en las jornadas catalogadoras pobres en elementos artísticos (Gómez-Moreno 1904, Lorenzo \& Pérez Martín 2017, 116). Tampoco había nada medieval en el programa de Arqueología de la Universidad Central en 
1913 (Mélida 1913). Mediante este cambio de percepción sobre la disciplina, Gómez-Moreno parece reivindicar su vigencia en el $\mathrm{CEH}$, justo cuando la Prehistoria está perfeccionando sus procedimientos.

Su discípulo Antonio Floriano (Floriano 1970, 149) asegura que don Manuel sabía excavar por haber acompañado a Mélida en las campañas emeritenses, aunque es un dato que encaja mal en la relación que mantuvieron (Díaz-Andreu 2004, 44). Que Gómez-Moreno no excavara no le retira la condición de arqueólogo (Almela Boix 1991, 133), más aún cuando son frecuentes las aproximaciones «estratigráficas» en sus análisis arquitectónicos (Gómez-Moreno 1905, 92; 1949b, 405). Sí fueron arqueólogos excavadores algunos de sus discípulos como Mergelina, Camps o Íniguez (Bellón Ruiz 2015, 16). Aunque reseñables, no son méritos para situarlo a la vanguardia de una Arqueología en la que, por esos mismos años, comienzan a asomar — no generalizadamente — trabajos con sólidas bases estratigráficas (Beltrán Fortes 2011, 33, Díaz-Andreu 1997, 404, González Reyero 2007, 343). Resulta extraño que una personalidad tan inquieta como la del maestro granadino no estuviera al tanto de esos avances. Podría especularse que los mirase con recelo por vincularse estrechamente a los estudios prehistóricos.

Suponemos esto porque su relación con los prehistoriadores del momento estuvo marcada por prejuicios. Lamentaba que la Prehistoria renunciara a análisis histórico-artísticos (Bellón Ruiz 2015, 220), considerándola «ciencia orgullosa que, si tiene base firme y respetable en la geología y en la paleontología, desdeña en cambio la historia y tropieza contra el sentido común» (Gómez-Moreno 1907, 6). A este clima de hostilidad contribuyen ciertos desencuentros personales, como el enfrentamiento escenificado con Obermaier durante el crucero universitario por el Mediterráneo de 1933 (Gómez-Moreno 1995, 419) y, sobre todo, en la dura carta enviada a Bosch a propósito de la publicación del libro de este, Etnología de la Península Ibérica (Bellón Ruiz 2015, 225). Desconfiaba de algunos de los extranjeros que ayudaron a su introducción (Bellón Ruiz 2015, 25) y censuraba los tintes nacionalistas alcanzados en escuelas como la catalana a partir de la conexión Puig i Cadafalch-Bosch Gimpera (Blech 2002, 106). Significativamente, en 1929 durante el IV Congreso Internacional de Arqueología de Barcelona, don Manuel dirigió la sección de arqueología paleocristiana y visigoda (Bellón Ruiz 2015, 103), ámbito más propio de la «erudición artística» (Peiró Martín \& Pasamar Alzuria 1989-90, 25) y adecuado a sus intereses.

\subsection{Iglesias Mozárabes. El estímulo noventayochista}

La temática de estas iglesias (figura 4) no resulta novedosa, pues otros ya habían reivindicado el protagonismo de los mozárabes (Simonet 1897-1903) y el aporte andalusí a la Historia y el Arte españoles (Rodríguez Domingo 1997, 342). Su novedad radica en utilizar estos ingredientes para construir un relato ajustado al principio regeneracionista de búsqueda del espíritu cultural nacional a través de la modernización del método y el instrumental científico (López-Ocón 1999, 147, Varela 1999, 251). Podemos considerar a Gómez-Moreno como el equivalente en la Historia del Arte a Unamuno, en Literatura, o a Altamira, en la Teoría de la Historia, a partir del viraje desde el nacionalismo político a la historia cultural como medio para reconocer la civilización española, de ahí su perfecto encaje en el CEH. Su gran mérito consiste en superar el discurso identitario y político de los estilos nacionales decimonónicos, basados en el principio hegeliano del Volkgeist (Dacosta 2004, 45-49), hasta concebir un modelo en el que la cultura y el arte trascienden las fronteras políticas para constituir la base de una sociedad con rasgos democráticos que debían ser reivindicados en el presente. 


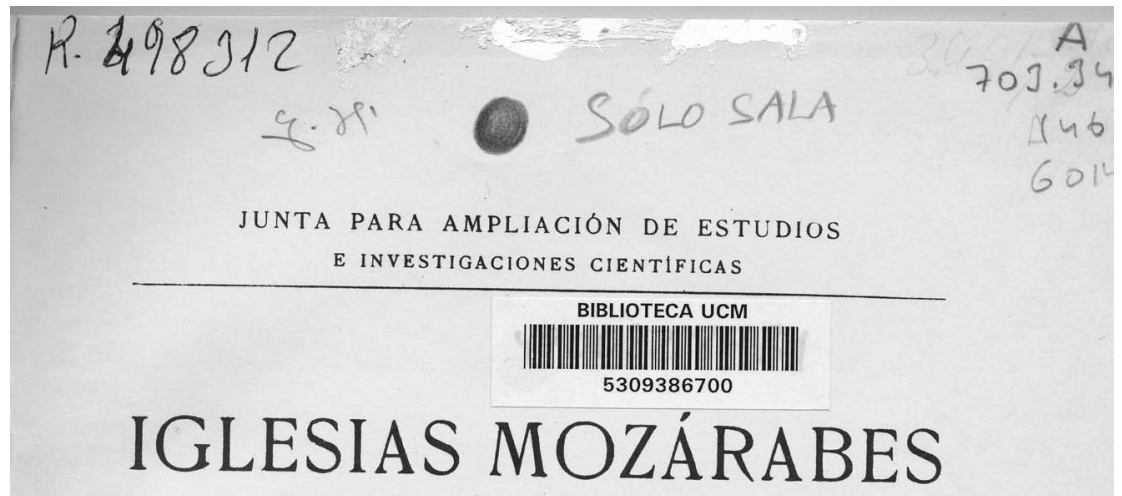

ARTE ESPAÑOL

DE LOS SIGLOS IX A XI

POR

M. GÓMEZ-MORENO

CENTRO DE ESTUDIOS HISTÓRICOS

M A D R I D

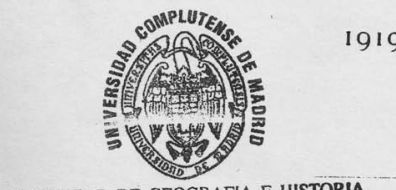

DE GEOGRAFIA E HISTORIA

BI BLIOTECA

919

Figura 4. Portada de Iglesias mozárabes (Gómez-Moreno 1919).

Gómez-Moreno (1919, XI) no cree en el concepto de unidad nacional para el período altomedieval. La nación no se había forjado en 589 cuando Iglesia y reino confluyeron (Moreno Martín 2017), de ahí que tampoco los mozárabes pudieran defenderla (Rodríguez Mediano 2002, 87), tal y como sostenían Simonet (1897-1903) o Menéndez Pelayo (1880). Su arte mozárabe no es nacional pero sí representa el espíritu de un pueblo libre, rebelde, cuya forja se realiza a partir del individualismo y la resistencia frente a influjos germánicos europeos (Barbe-Coquelin de Lisle 1977, 177). Una sociedad que acepta cuanto llega de Oriente — como había sido desde la prehistoria- 
por la vía de la arabización, mientras reacciona impulsivamente contra otras corrientes extranjeras. Así comenta que «cuanto más se va estudiando el arte de nuestro país más se echa de ver la continua avalancha de artistas extranjeros que invadieron España en todos tiempos» (carta a su padre, 1904 en Lorenzo \& Pérez Martín 2017, 268). Lo mozárabe, al igual que nuestras particulares versiones del románico y del gótico (Gómez-Moreno 1934), constituye un eslabón del genio artístico español que recorre la historia; discontinuo, individualista y anárquico. Los edificios solo son una porción de la cultura mozárabe cuyo legado componen otros objetos y textos (Gómez-Moreno 1919, IX). Al abrir esta puerta, se adentra en una sociedad fosilizada entre la época visigoda y la Reconquista feudal que considera depositaria de la esencia intemporal del genio español (Rodríguez Mediano 2002, 82), dentro de la «moral de la ciencia» y el espíritu colectivo practicadas en el CEH (Olmos Romera 2012, 35).

$\mathrm{Su}$ propia concepción de la historia permite rastrear el origen de este genio dentro del modelo «gomezmoreniano» (Varela 1999, 251). Este leitmotiv lo representa, desde la Prehistoria, el factor oriental de la cultura peninsular (Bellón Ruiz 2015, 128): «El neolitismo ibérico es obscuro, pero no es misterioso; porque a través del Mediterráneo, se descubre su génesis o paralelismos o identidades de arte, probando comunicación entre lo nuestro y lo oriental, una fraternidad cuya alianza con lo egipcio y asiático no se pone en duda; todo son ramificaciones de un mismo árbol; todo constituye el mundo civilizado» (Gómez-Moreno 1907, 7). La progenie oriental surca el devenir de la historia ibérica a través del megalistismo andaluz (Gómez-Moreno 1905, 99) y el orientalismo tardoantiguo por vía norteafricana en la Bética (Gómez-Moreno 1907, 30). Por eso, «orientalizarse fue pan comido» tras la conquista islámica y la llegada de una cultura más refinada cuyas ciudades contrastan con las sucias urbes cristianas (Gómez-Moreno 1974, 334) nos distinguió de las demás naciones europeas hasta dominarlas pacíficamente (Gómez-Moreno $1970 \mathrm{~b}, 68,70,71)$. Este planteamiento sobrepasa los límites de la alta Edad Media y funciona como deus ex machina para explicar las particularidades del arte peninsular. De esta forma, el mudéjar es el refugio español frente al vendaval gótico (Gómez-Moreno 1934, 12). Defiende igualmente su papel dinamizador contrapuesto al resto del arte europeo. En Granada, el orientalismo resistió hasta que llegaron los extranjerismos de los Reyes Católicos y los Austrias (GómezMoreno 1907, 30).

Regresando a lo mozárabe, el alcance de su definición rebasa ampliamente lo artístico para conceptualizar una sociedad cuyos valores deben reivindicarse como esencia de lo español. Valores mantenidos intactos en lugares como Bobastro, la ciudadela rebelde del siglo Ix contra las arbitrariedades de los emires cordobeses (Gómez-Moreno 1995, 393). En las iglesias levantadas por los monjes sin oprimir a los siervos que reflejan un ambiente social libre y democrático, pleno de orientalismos arraigados en los fugitivos que huyeron de al-Andalus y cuya presencia frenó el avance feudal que invadía el resto de Europa. Sus profundas raíces arraigaron en Castilla, perpetuándose en el «labriego prosaico, tranquilo, contento con mirar crecer sus mieses» (Gómez-Moreno 1919, XIII, 139) quedando meridianamente clara su fidelidad a los postulados noventayochistas.

\subsection{IGLESIAS MOZÁRABES. El EDIFICIO COMO OBJETO ARQUEOLÓGICO}

El libro Iglesias Mozárabes. Arte Español de los siglos IX a XI (1919) se articula en torno a la premisa regeneracionista de modernización de los medios de investigación, aquí, según creemos, a partir de la intersección metodológica entre la Historia del Arte y la Arqueología. El sistema se rige 
por un principio de ordenación positivista. Una vez llegados al edificio procedían a «tocar, oler, fotografiar, medir...» (así describe su primer encuentro con San Pedro de la Mata el año 1910 acompañado de Torres Balbás y Nebot, Castillejo 1998, 127), en suma, a recopilar cuantos datos les permitía el instrumental disponible con el doble objetivo de garantizar el rigor expositivo y, llegado el caso, la calidad de futuras restauraciones (Blech 2002, 90, Dacosta 2004, 52, Bellón Ruiz 2015, 69). El estudio se esfuerza en presentar los edificios «uno a uno con su verdad propia; que la crítica lo analice», dice en el preámbulo (Gómez-Moreno 1919, X). Un posicionamiento similar al de otros arqueólogos excavadores de su generación (Díaz-Andreu 2004, 110). Es también importante subrayar su excepcional aportación (también de sus discípulos) en la práctica de la conservación de edificios históricos, aunque, por cuestiones de espacio, no podemos abordarla y remitimos al lector al balance que ofrece García Cuetos (2011).

Para el trabajo de campo utiliza tres herramientas: la excursión, el dibujo y la fotografía. Entiende la excursión como trabajo colaborativo que llevaba a ponerse frente al monumento y ver. No parece temerario relacionar este verbo con el uso que la ILE hace del mismo siguiendo el texto de Cossio Carácter de la pedagogía contemporánea. El arte de saber ver (Cossío 1879). Se volvía tantas veces como fuera necesario. Hasta en tres ocasiones visitó algunos edificios con sus ayudantes Torres, Nebot, Allende-Salazar y Moreno Villa (Gómez-Moreno 1919, XXII). Si para documentar las fases originarias era preciso retirar adiciones posteriores, se procedía a hacerlo. Esta práctica, censurable actualmente, permitió «descubrir» el edificio altomedieval de San Salvador en Palat de Rey (León), «a peńazo limpio y con unas varas de hierro nos dimos a derribar cosas, hasta dar con restos indudables no solo de los pilares de sillería que sostienen dicha bóveda, y arranques de muros linderos, sino que también de un ábside redondo que había a los pies de la iglesia» (Castillejo 1998, 162).

Visto y comprendido el edificio, era momento de anotar sus medidas sobre dibujos y croquis con los que, en la fase de gabinete, elaborar rigurosas planimetrías cuyo valor se acrecentaba al haber partido del análisis arqueológico. Resulta sorprendente que se considere un avance fundamental en la arqueología de subsuelo la presencia de arquitectos elaborando planimetrías (Casado Rigalt 2006, 274) cuando nuestro autor, incluso en su soledad de catalogador, traza planos de altísima calidad como el de la catedral de Zamora (Lorenzo \& Pérez Martín 2017, 57). A Gómez-Moreno le obsesiona el rigor en la toma de datos, y le desesperan las planimetrías publicadas incorrectamente que le hacen perder tiempo en la confección de las suyas propias (Castillejo 1998, 256). Iglesias Mozárabes enmienda bastantes incorrecciones gráficas anteriores (Gómez-Moreno 1919, 145). Especial interés revisten, por las características de los edificios mozárabes, las vistas axonométricas, toda una novedad en el estudio de la edilicia medieval (García Cuetos 2011, 140).

Sus colegas recuerdan cómo don Manuel jamás salía de casa sin un metro en el bolsillo (Menéndez Pidal 1970, 332), mientras sus discípulos rememoran, con más o menos agrado, las largas jornadas «midiendo ruinas en pleno campo» (Moreno Villa 1939 (2006), 71). Dibujaban cuantos detalles consideraban necesario, por ínfimos que fueran, en miles de pequeñas cuartillas con letra apretada que eran el más preciado tesoro de regreso al gabinete. Al dibujar interpretamos, decía el maestro (González Reyero 2007, 336), extraemos los rasgos que interesa remarcar para modelizar el objeto y afrontar su análisis tipológico (Caballero Zoreda \& Murillo 2006, 91).

Por su valor en las tareas de documentación —y solo como complemento del dibujo- introdujo la fotografía, técnica que conocía desde sus años en Granada, cuando desde ciertos ámbitos académicos se veía en ella la auténtica revolución arqueológica (González Reyero 2007, 200). No sin problemas, perfeccionó su manejo y las técnicas de revelado durante la elaboración de los 
catálogos, pues todas las imágenes eran «de mano del autor» (Gómez-Moreno 1910, 26). Cargaba con placas de vidrio de 13 x 18 en cámara oscura, trípode y el propio aparato, en transportes precarios o, directamente, a pie (Gómez-Moreno 1995, 115). En ocasiones, como sucedió en la excursión a San Pedro de la Nave (figura 5), las placas llegaban rotas, dificultando todavía más alcanzar resultados adecuados (Lorenzo \& Pérez Martín 2017, 46). Utilizaba un método de positivado de ennegrecimiento directo basado en el uso del papel al gelatino-cloruro de plata. El resultado tenía menor estabilidad pero era más sencillo que el positivado químico (González Reyero 2007, 222). Era buen conocedor de los procedimientos para mejorar la luminosidad de las tomas (Lorenzo \& Pérez Martín 2017, 105) que, sabemos, transmitía a sus colaboradores y su esposa, quien se convirtió en apoyo fundamental para el catálogo de Zamora: «sigo ejercitándome en las fotografías (...) para hacerlas yo mientras él toma notas» (Castillejo 1998, 274, Lorenzo \& Pérez Martín 2017, 149).

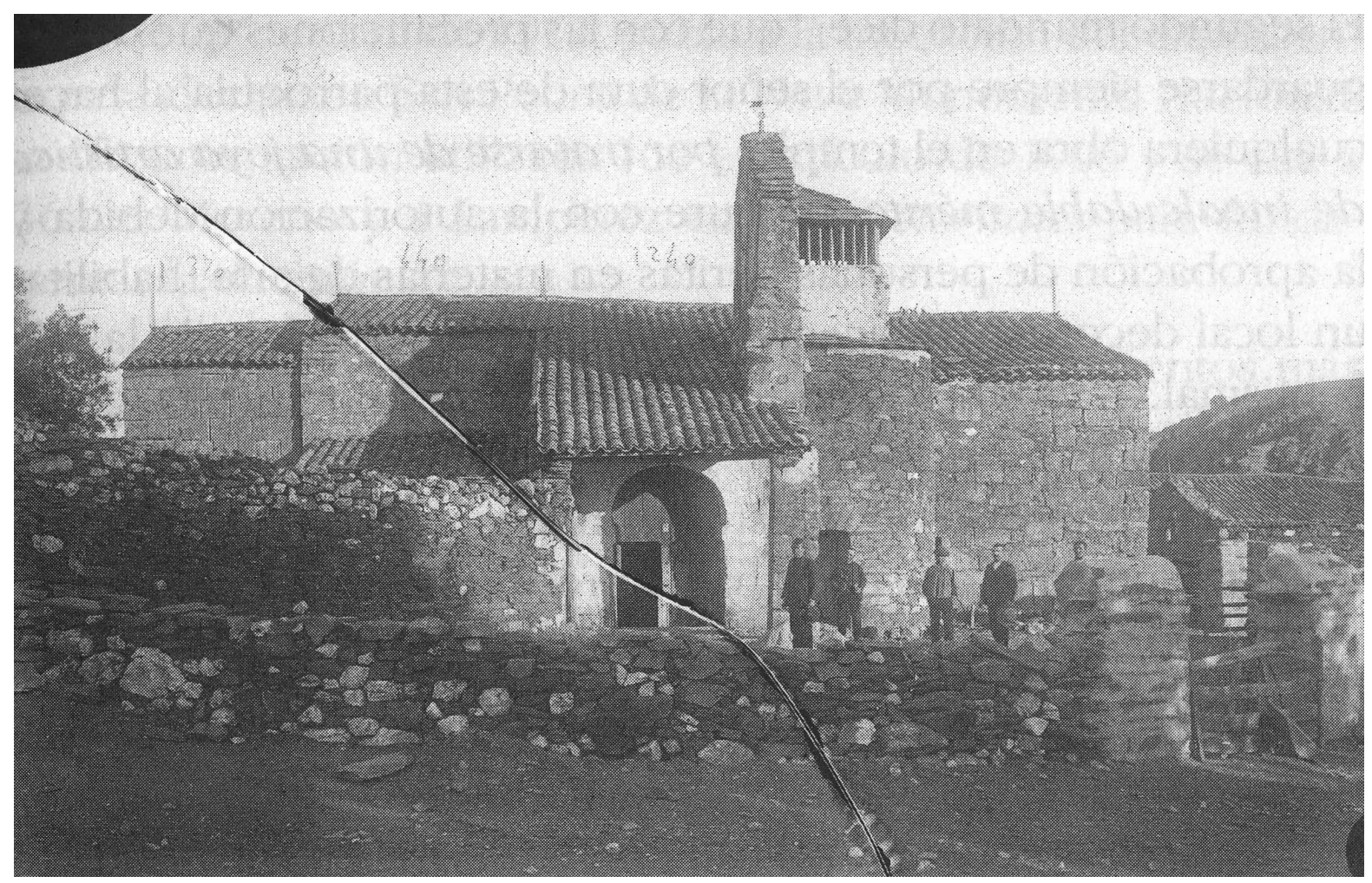

Figura 5. Placa fotográfica realizada en la excursión a San Pedro de la Nave en 1903 (Lorenzo \& Pérez 2017, 47).

El CEH contó desde sus orígenes, con un laboratorio de revelado (Cabañas Bravo 2014, 236) de manera que los alumnos asimilaron su importancia como instrumento científico (Orueta 2015, 222) y material docente (Angulo 1970, 228). Si se ha reivindicado el papel del CEH en la extensión del uso de la fotografía en la arqueología española de principios de siglo, parece injusto no reconocer el protagonismo de Gómez-Moreno en un proceso que, pocos años después, concluyó con su uso generalizado en tareas de documentación y difusión (González Reyero 2007, 210). 
Lo mostrado hasta aquí garantiza que la sección de Arqueología del CEH conocía y manejaba con solvencia el avanzado instrumental científico para la toma de datos del monumento. Al analizar sus bases metodológicas, estas sorprenden por su modernidad y carácter interdisciplinar, pues, al habitual uso de las fuentes, le suman aproximaciones tipológicas, tecnológicas y, con matices, estratigráficas. Estratigrafía, tipología y tecnología constituyen, según Schnapp (2002, 138), los tres pilares de la arqueología contemporánea.

Su dominio del latín y del árabe, junto a su experiencia epigráfica, avalan el manejo de manuscritos e inscripciones, esfuerzo paleográfico que tendrá recorrido posterior en la transcripción de los documentos altomedievales en pizarra (Gómez-Moreno 1966, 18). De los textos extrae información contextual y vocablos con los que actualizar el léxico técnico utilizado en las descripciones. La obsesiva búsqueda de términos adecuados (filológica, técnica e históricamente) es una constante en su trayectoria (Bellón Ruiz 2015, 153): capiteles «entregos», «ajimez» o «alfiz» son algunos de ellos (Gómez-Moreno 1910, 5; 1919, 13). Surge así una primera nómina de edificios acompañada de un detallado estudio prosopográfico de la mozarabía leonesa y de los oficios que desempeñaban (Gómez-Moreno 1919, XVII, 108-129).

Concluido el trabajo filológico y de documentación gráfica, se inicia un proceso que, de acuerdo a los estándares actuales, podría aproximarse a los procedimientos de Arqueología de la Arquitectura. Aunque no individualiza unidades estratigráficas, distingue etapas constructivas en las que situar elementos tipologizables (Utrero 2005, 27). Estas apreciaciones — muchas de las cuales proceden de su trabajo de catalogación (Gómez-Moreno 1910) — eran completadas con las vertidas por sus colaboradores durante las tareas de campo y, en ocasiones, aprovechando restauraciones en marcha (Gómez-Moreno 1919, 12). Veamos algunos ejemplos.

En Melque, considera posteriores a la fábrica primitiva la «habitación de los arcos» y la torre sobre el cimborrio, al tiempo que identifica el desaparecido pórtico occidental, habiéndose confirmado estos aspectos en investigaciones posteriores (Caballero Zoreda 2004). En Escalada, pese a la disparidad material, considera de una fase toda la caja del edificio y documenta sus accesos originarios. En el pórtico sur, de una etapa posterior, pero todavía altomedieval, identifica dos fases constructivas. Además, en algunas de las planimetrías introduce detalles gráficos para distinguir la antero-posterioridad de ciertos elementos, concretamente las figuras 4, 6, 13, 20, $22,25,43,54,75,93$ y 125 . Las once perspectivas axonométricas son de enorme utilidad, especialmente para la comprensión de los sistemas de cubierta (figura 6), constituyendo una modalidad de plano fundamental en los análisis de edificios históricos (Caballero Zoreda \& Murillo 2006, 89).

Aunque la falta de uniformidad en las trazas de los edificios del grupo imposibilita la confección de una tipología (Gómez-Moreno 1919, XVIII), no renuncia a la estrategia comparativa de elementos individuales: arcos y ábsides de herradura, bóvedas gallonadas y nervadas (enmienda el grave error de Lampérez, quien las consideró góticas, Gómez-Moreno 1919, 304), aleros con modillones y capiteles corintizantes, creando sistemas que relacionan las iglesias entre sí y el conjunto con manifestaciones al otro lado de la frontera con al Andalus (Gómez-Moreno 1919, 301). En última instancia sitúa la unidad de estos monumentos mozárabes en su base tecnológica que se encarga de caracterizar describiéndola minuciosamente. Materiales (incluyendo caracterizaciones geológicas, Gómez-Moreno 1919, 146, perspectiva recientemente revisitada con notables resultados, Álvarez et al. 2017), sistemas de aparejo, morteros, revestimientos, técnicas decorativas y huellas de talla desfilan por sus hojas acompañados de dibujos, secciones, alzados y despieces que ayudan a su definición. 


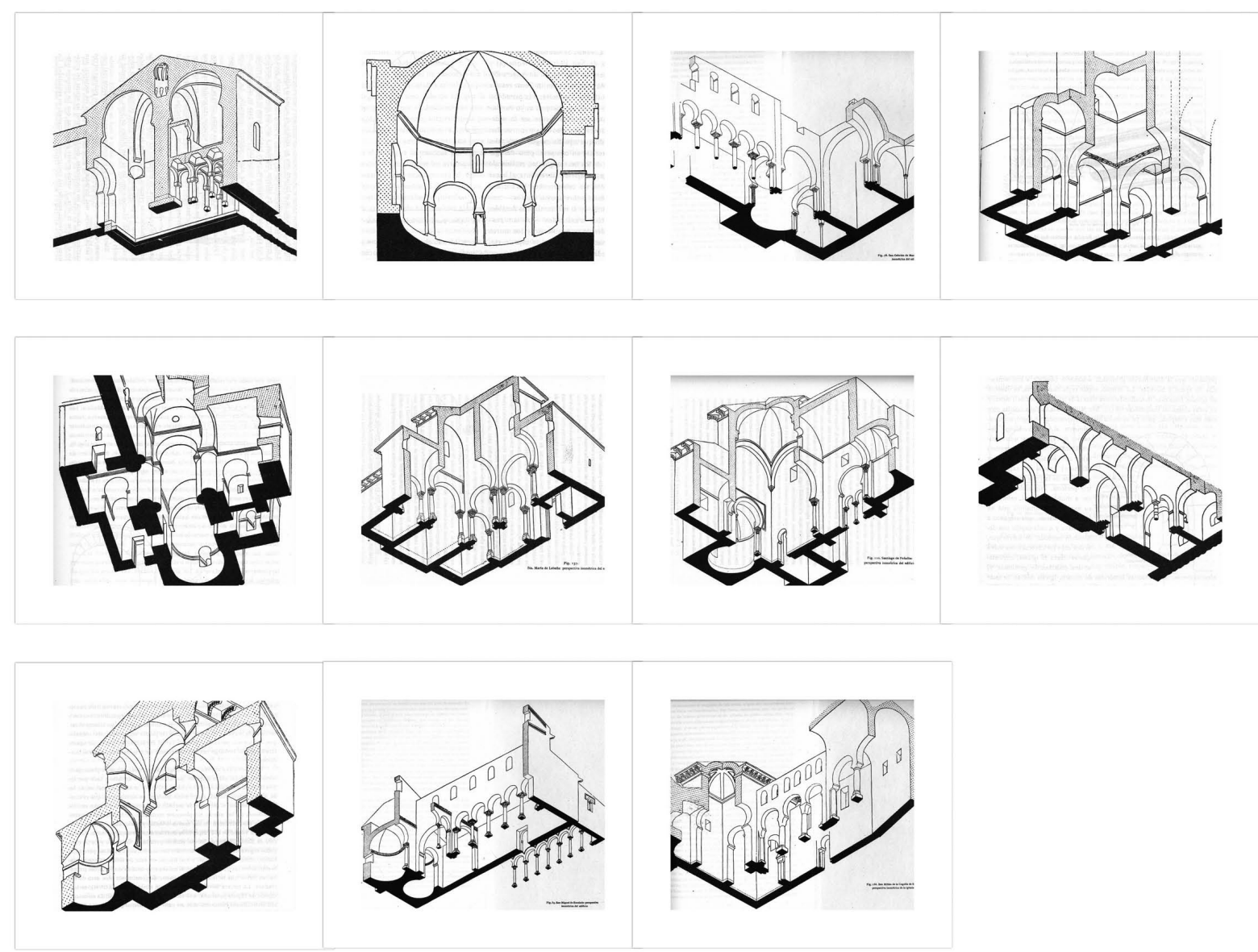

Figura 6. Visiones axonométricas de los edificios mozárabes (Gómez-Moreno 1919).

\section{Conclusiones}

Iglesias Mozárabes es un libro modélico por su rigor, interdisciplinariedad metodológica, honestidad científica, trabajo en equipo y minuciosidad en la documentación. Hombre de fuertes convicciones ideológicas, liberalismo, nacionalismo y catolicismo se injertan sutilmente (o, en ocasiones, abruptamente) en su investigación a lo largo de su centenaria vida, lo que no ha de restar méritos a su capacidad de sacrificio y altísimo nivel de profesionalización. Reconocido por sus discípulos y por muchos investigadores actuales como piedra angular de los estudios arqueológicos y artísticos de nuestra Edad Media (fiel cumplidor, por ello, de los presupuestos de la JAE), no ha faltado quien, desde las trincheras del corporativismo mal entendido, han sancionado esta perspectiva integradora. La crítica más injusta —e incomprensible por el lugar donde aparece- es la vertida por Bango (1998) en el estudio preliminar que acompaña la reedición de Iglesias Mozárabes, a propósito de la base teórica del arte mozárabe, que tacha de simplificada, sesgada y equívoca. 
Cierto que don Manuel no es arqueólogo de excavación y que su visión estratigráfica apenas está esbozada, pero no lo es menos que su perfil era habitual en los años en los que alcanzó la madurez intelectual y profesional (1900-1935). El inicio de la implantación de la estratigrafía en España se produjo cuando él enfilaba la jubilación. Tras la guerra, su perspectiva «orientalista» de la historia y la influencia andalusí en la cultura hispana fueron arrinconadas por la lectura céltico-germánica, condenando a un cierto ostracismo algunos de sus trabajos de pre/protohistoria, el mozárabe y el románico. Al cumplirse el primer centenario de Iglesias Mozárabes, es justo, cuando menos, reconocer su extraordinaria importancia para el conocimiento de un arte, el altomedieval español, que, hasta su aparición estaba «sin estudiar dignamente aún».

A lo largo de este estudio, creemos haber podido distinguir una serie de trasvases metodológicos que, desde la perspectiva arqueológica de su tiempo, contribuyeron al avance en el análisis de nuestros monumentos prerrománicos. A partir de su trabajo, y siempre que se pretenda superar lo dicho por el investigador granadino, es inexcusable el conocimiento directo del edificio, su actualización planimétrica y la aproximación secuencial y tipológica. De no proceder así, incurriremos en análisis estériles y superficiales, por desgracia, todavía frecuentes.

\section{BibLIOGRAFÍA}

Almagro, M., 2004, «La Real Academia de la Historia, una institución al servicio de la arqueología española», en: M. Ayarzagüena Sanz \& G. Mora (eds.), Pioneros de la Arqueología en España. [Zona Arqueológica 3], Madrid: Museo Arqueológico Regional, 55-68.

Almela Borx, M. A., 1991, "La aportación de José Ramón Mélida a la consolidación de la Arqueología como disciplina científica en España», en: J. Arce \& R. Olmos (eds.), Historiografía de la arqueología y de la Historia antigua en España. Madrid: Ministerio de Cultura, 131-134.

Álvarez, E., M. de la Á. Utrero \& J. Manuel Baltuille, 2017, Geología y Arqueología. Estratigrafía de la tierra, estratigrafía del patrimonio, Madrid: Instituto Geológico y Minero de España.

Angulo, D., 1970, «Algunos de mis recuerdos de don Manuel Gómez-Moreno», Homenaje a Gómez-Moreno. 1870-1970, Granada: Universidad de Granada, 227-232.

Arciniega García, L., 2014, Elías Tormo y Monzó (1869-1957) y los inicios de la Historia del Arte en España. [Maestros de la Historia del Arte], Granada: Comité Español de Historia del Arte.

Arnaldo, J., 2016, "Las visitas escolares al Museo del Prado», en: S. Guerrero (ed.), El Arte de saber ver. Manuel B. Cossio, la Institución Libre de Enseñanza y El Greco, Madrid: Institución Libre de Enseñanza, 261-271.

Azuar, R., 2016, «De Arqueología Mozárabe II. De sus iglesias y documentos epigráficos», Arqueología y Territorio Medieval 23, 75-102.

Balmaseda, L. J., 1997, «El modelo de Guarrazar: Real Academia de la Historia y presidiarios en una excavación decimonónica», en: G. Mora \& M. Díaz-Andreu (eds.), La cristalización del pasado. Génesis y desarrollo del marco institucional de la arqueología en España. Actas del II Congreso Internacional de Historiografía de la Arqueología en España (siglos XVIII-XX), Madrid, Málaga: Ministerio de Cultura, Universidad de Málaga, 207-214.

Bango Torviso, I. G., 1998, «Estudio preliminar», en: M. Gómez-Moreno (ed.), Iglesias mozárabes. Arte español de los siglos IX a XI [Edición facsimil], Granada: Universidad de Granada.

Barbe-Coquelin de Lisle, G., 1977, "Manuel Gómez Moreno y el 98», Actas del Quinto Congreso de la Asociación Internacional de Hispanistas: celebrado en Bordeaux del 2 al 8 de septiembre de 1974, Burdeos: Instituto de Estudios Ibéricos e Iberoamericanos, Université de Bordeaux III, 171-178.

Bellón Ruiz, J. P., 2010, «De Arquitectura Tartesia: los dólmenes de Antequera en el contexto de la obra de Manuel Gómez-Moreno Martínez», Menga 1, 115-133. 
Bellón Ruiz, J. P., 2015, «Manuel Gómez-Moreno: 100 años de arqueología española», en: M. GómezMoreno (ed.), Adam y la prehistoria, Pamplona: Urgoiti, VII-CCLXIV.

Beltrán Fortes, J., 2011, "Historia de la Arqueología andaluza de 1860 a 1936. En el marco vital de Luis Siret (1860-1934)», en: M. Sánchez Romero (ed.) Memorial Luis Siret. I Congreso de Prehistoria de Andalucía, Sevilla: Junta de Andalucía, 25-38.

BLECH, M., 2002, «Las aportaciones de los arqueólogos alemanes a la arqueología española», en: S. Quero Castro \& A. Pérez Navarro (eds.), Historiografía de la Arqueología Española. Las Instituciones, Madrid: Museo de San Isidro, 83-117.

Caballero Zoreda, L., 1977, "La «forma en herradura» hasta el siglo viII y los arcos de herradura de la iglesia visigoda de Santa María de Melque», Archivo Español de Arqueología 50-51 (135-138), 323-374.

Caballero Zoreda, L., 1996, «El análisis estratigráfico de construcciones históricas», en: C. Escribano \& L. Caballero (eds.), Arqueología de la Arquitectura, Burgos: Junta de Castilla y León, 55-74.

Caballero Zoreda, L., 2004, «Excavaciones arqueológicas en el lugar de Melque. San Martín de Montalbán (Toledo)», Investigaciones arqueológicas en Castilla-La Mancha. 1996-2002, Toledo: Junta de Comunidades de Castilla-La Mancha, 345-363.

Caballero Zoreda, L., 2010, «Vida y trabajo de Manuel Gómez-Moreno. con la arquitectura altomedieval como tema», en: N. Schlanger \& J. Nordbladh (eds.) Coloquio Centenario del Centro de Estudios Históricos, Madrid: Consejo Superior de Investigaciones Científicas.

Caballero Zoreda, L., \& J. I. Murillo, 2006, «El dibujo arqueológico. Notas sobre el registro gráfico en arqueología», Papeles del Partal 3, 75-95.

Cabañas Bravo, M., 1995, "José Moreno Villa. Un historiador del Arte sin márgenes», Historiografía del arte español en los siglos XIX y XX (VII Jornadas de Arte. Departamento de Historia del Arte del CEH del CSIC), Madrid: Editorial Alpuerto-CSIC, 381-396.

Cabañas Bravo, M., 2007, «La Historia del Arte en el Centro de Estudios Históricos», en: M. A. PuigSamper (ed.), Tiempos de investigación: JAE-CSIC, cien años de ciencia en España, Madrid: Consejo Superior de Investigaciones Científicas, 143-154.

Cabañas Bravo, M., 2014, «El fichero de Arte Antiguo de 1931, fondo fotográfico e instrumento administrativo para el estudio y protección del arte», en: M. Cabañas Bravo \& W. Rincón García (eds.), El arte y la recuperación del pasado reciente, Madrid: Consejo Superior de Investigaciones Científicas, 231-252.

Camps Cazorla, E., 1935, El Arte Románico en España, Madrid: Labor.

Casado Rigalt, D., 2006, José Ramón Mélida y la arqueología española, Madrid: Real Academia de la Historia.

Castillejo, D., 1998, Los intelectuales reformadores de España. Epistolarios de José Castillejo y de Manuel Gómez-Moreno. El espiritu de una época II, Madrid: Castalia.

Contreras, J. De, 1970, "Mis recuerdos de don Manuel Gómez-Moreno», Homenaje a Gómez-Moreno. 1870-1970, Granada: Universidad de Granada, 209-216.

Cortadella, J., 1997, "La investigación arqueológica en las asociaciones excursionistas catalanas (18761915)», en: G. Mora \& M. Díaz-Andreu (eds.), La cristalización del pasado. Génesis y desarrollo del marco institucional de la arqueología en España, Madrid, Málaga: Ministerio de Cultura, Universidad de Málaga, 273-286.

Cossío, B. DE, 1879, "Carácter de la Pedagogía Contemporánea. El arte de saber ver», Boletín de la Institución Libre de Enseñanza 3 (65), 153-154.

Dacosta, T., 2004, Toward a Geography of Art, Chicago: The University of Chicago Press.

Díaz-Andreu, M., 1997, "Nación e internacionalización. La arqueología en España en las tres primeras décadas del siglo xx», en: G. Mora \& M. Díaz-Andreu (eds.), La cristalización del pasado. Génesis y desarrollo del marco institucional de la arqueología en España, Madrid, Málaga: Ministerio de Cultura, Universidad de Málaga, 403-416.

DíAz-Andreu, M., 2004, «Mélida: génesis, pensamiento y obra de un maestro», en: J. R. Mélida (ed.), Arqueología española. [Clásicos de la historiografía española], Pamplona: Urgoiti, I-CXCIX.

Fernandes, P. A., 2003, «O contributo de D. Fernando de Almeida para o estudo da Alta Idade Média em Portugal», Revista Arqueologia e História 55, 205-213. 
Floriano, A., 1970, «Yo buscaba un guía. Fragmentos de una autobiografía impublicada e impublicable», Homenaje a Gómez-Moreno. 1870-1970, Granada: Universidad de Granada, 147-154.

García Cuetos, P., 2011, «La renovación de la Historia de la Arquitectura y del Arte en las primeras décadas del siglo xx: Manuel Gómez-Moreno», en: M. P. Biel Ibáńez \& A. Hernández Martínez (eds.), Lecciones de los maestros. Aproximación histórico-critica a los grandes historiadores de la arquitectura española, Zaragoza: Institución Fernando el Católico, 125-158.

Gaya Nuño, J. A., 1970, "Gómez-Moreno a los noventa años», Homenaje a Gómez-Moreno. 1870-1970, Granada: Universidad de Granada, 161-168.

Gaya Nuño, J. A., 1975a, Historia de la Crítica de Arte en España, Madrid: Ibérico Europea de Ediciones.

Gaya Nuño, J. A., 1975b, Historia de la crítica del Arte en España, Madrid: Ibérico Europea de Ediciones.

Gómez-Moreno (GonzÁlez), M., 1892, Guía de Granada, Granada: Imprenta de Indalecio Ventura.

Gómez-Moreno Calera, J. M., 2016, Manuel Gómez-Moreno Martínez (1870-1970), Granada: Comité Español de Historia del Arte.

Gómez-Moreno, M., 1904, «Sobre Arqueología primitiva en la región del Duero», Boletín de la Real Academia de la Historia 45, 147-160.

Gómez-Moreno, M., 1905, "Arquitectura tartesia: la necrópolis de Antequera», Boletín de la Real Academia de la Historia XLVII, 81-132.

Gómez-Moreno, M., 1906, Excursión a través del arco de herradura, Madrid: Imprenta Ibérica.

Gómez-Moreno, M., 1907, Monumentos Arquitectónicos de España. Granada y su provincia, Madrid: Gaceta de Madrid.

Gómez-Moreno, M., 1910, Catálogo Monumental de España. Provincia de León, Manuscrito.

Gómez-Moreno, M., 1913, «De Arqueología Mozárabe», Boletin de la Sociedad Española de Excursiones 21, 89-116.

Gómez-Moreno, M., 1919, Iglesias Mozárabes. Arte Español de los siglos IX a XI, Madrid: Centro de Estudios Históricos.

Gómez-Moreno, M., 1928 (1974), La novela de España. [La Vela Latina/Historia], Madrid: Ediciones Júcar.

Gómez-Moreno, M., 1934, El Arte Románico Español. Esquema de un libro, Madrid: Centro de Estudios Históricos.

Gómez-Moreno, M., 1949a, El libro español de arquitectura, Madrid: Magisterio Español.

Gómez-Moreno, M., 1949b, Misceláneas. Historia, Arte, Arqueología (dispersa, enmendata, addita, inédita), Madrid: Consejo Superior de Investigaciones Científicas.

Gómez-Moreno, M., 1966, Documentación goda en pizarra, Madrid: Real Academia de la Historia.

Gómez-Moreno, M., 1970a, «Don Manuel cuenta su vida en los ańos decisivos», Homenaje a Gómez-Moreno. 1870-1970, Granada: Universidad de Granada, 9-31.

Gómez-Moreno, M., 1970b, Retazos. Ideas sobre Historia, Cultura y Arte, Madrid: Consejo Superior de Investigaciones Científicas.

Gómez-Moreno, M. E., 1995, Manuel Gómez-Moreno Martínez, Madrid: Centro de Estudios Ramón Areces.

González, R., 1993, «Los forjadores de la historia tardoantigua: Don Manuel Gómez-Moreno», Antigüedad y Cristianismo 10, 667-673.

González Reyero, S., 2007, La fotografía en la Arqueología Española (1860-1960). Cien años de discurso arqueológico a través de la imagen. [Historia. Antiquaria Hispánica 15], Madrid: Real Academia de la Historia.

Gozalbes Cravioto, E., 2005, «Los inicios de la investigación española sobre arqueología y arte árabes en Marruecos (1860-1960)», Boletín de la Asociación Española de Orientalistas XLI, 225-246.

Guerrero, S., 2016, "Cossío, la Institución Libre de Enseñanza y el Arte de saber ver», en: S. Guerrero (ed.), El Arte de saber ver. Manuel B. Cossio, la Institución Libre de Enseñanza y El Greco, Madrid: Institución Libre de Enseñanza, 25-47.

Gutiérrez, V., 1970, «Quince minutos con don Manuel Gómez-Moreno», Homenaje a Gómez-Moreno. 1870-1970, Granada: Universidad de Granada, 91-98. 
Hernández Hernández, F., \& E. de Frutos González, 1997, «Arqueología y museología: la génesis de los museos arqueológicos», en: G. Mora \& M. Díaz-Andreu (eds.), La cristalización del pasado. Génesis $y$ desarrollo del marco institucional de la arqueología en España, Madrid, Málaga: Ministerio de Cultura, Universidad de Málaga, 141-148.

HüBner, E., 1888, La Arqueología de España, Barcelona: Tipo-Litografía de los Sucesores de Ramírez y Cía.

Huergo, H., 2001, José Moreno Villa. Temas de Arte. Selección de escritos periodísticos sobre pintura, escultura, arquitectura y música (1916-1954), Madrid: Pre-textos.

Lampérez y Romea, V., 1908, Historia de la Arquitectura Cristiana Española. Vol.1, Madrid: Espasa-Calpe.

López-Ocón, L., 1999, "Manuel Gómez-Moreno en el taller del Centro de Estudios Históricos», en: J. Blánquez Pérez \& L. Roldán Gómez (eds.), La cultura ibérica a través de la fotografía de principios de siglo (II). Las colecciones madrileñas, Madrid: Universidad Autónoma de Madrid; Real Academia de la Historia; Comunidad de Madrid; Caja de Ahorros, 145-153.

López Sánchez, J. M., 2006, Heterodoxos españoles. El Centro de Estudios Históricos, 1910-1936, Madrid: Marcial Pons-Consejo Superior de Investigaciones Científicas.

Lorenzo, J., \& S. Pérez Martín, 2017, Excursiones Zamoranas, 1903-1904. Epistolario de Manuel GómezMoreno y Elena Rodriguez-Bolivar, [Biblioteca de Cultura Tradicional Zamorana 39], Zamora: Editorial Semuret.

Mederos Martín, A., 2018, «La formación arqueológica y en historia del arte del joven Manuel GómezMoreno Martínez (1870-1899)», en: S. España-Chamorro, R. Arranz Santos \& A. Romero Molero (eds.), Colecciones, Arqueólogos, Instituciones y Yacimientos en la España de los siglos XVIII al XX, Oxford: Archaeopress, 109-126.

Mélida, J. R., 1913, Programa de Arqueología, Madrid: Facultad de Filosofía y Letras. Universidad Central.

Menéndez Pidal, G., 1970, «El recuerdo vivo de don Manuel. Homenaje a Gómez-Moreno. 1870-1970», Homenaje a Gómez-Moreno. 1870-1970, Granada: Universidad de Granada, 329-336.

Menéndez y Pelayo, M., 1880, Historia de los Heterodoxos españoles, Madrid: Librería Católica de San José.

Moreno Martín, F. J., 2014, «Arqueología de la Arquitectura. Una visión conciliadora desde la Historia del Arte», Arqueología de la Arquitectura 11, e009. doi: http://dx.doi.org/10.3989/arq.arqt.2014.008.

Moreno Martín, F. J., 2017, "Visigoths, Crowns, Crosses and the Construction of Spain», Memoirs of the American Academy in Rome 62, 41-64.

Moreno Villa, J., 1939 (2006), Vida en claro. Autobiografía. [Colección Letras madrileñas contemporáneas], Madrid: Visor.

Moya, J., 2004, Manuel Gómez-Moreno González. Obra dispersa e inédita, Granada: Fundación RodríguezAcosta.

Olmos Romera, R., 2012, «D. Manuel Gómez-Moreno (1870-1970). Un esbozo impaciente de lecturas», El Instituto Gómez-Moreno, Fundación Rodríguez-Acosta (Granada), Exvotos Ibéricos, 2, Jaén: Instituto de Estudios Giennenses, 15-42.

Orueta, R. DE, 2015, La escultura española de los siglos XI y XII, Valladolid: Museo Nacional de Escultura.

Otero, L. E., 2017, La ciencia en España, 1814-2015. Exilios, retornos, recortes, Madrid: Catarata.

Peiró Martín, I., \& G. Pasamar Alzuria, 1989-90, «El nacimiento en Espańa de la arqueología y la prehistoria (academicismo y profesionalización, 1856-1936)», Kalathos 9-10, 9-30.

Rivière Gómez, A., 1997, «Arqueólogos y arqueología en el proceso de construcción del Estado nacional español (1834-1868)», en: G. Mora \& M. Díaz-Andreu (eds.), La cristalización del pasado. Génesis y desarrollo del marco institucional de la arqueología en España, Madrid, Málaga: Ministerio de Cultura, Universidad de Málaga, 133-140.

Rodríguez Domingo, J. M., 1997, «La Alhambra arqueológica (1847-1907): el origen de un modelo anticuario», en: G. Mora \& M. Díaz-Andreu (eds.), La cristalización del pasado. Génesis y desarrollo del marco institucional de la arqueología en España, Madrid, Málaga: Ministerio de Cultura, Universidad de Málaga, 341-350. 
Rodríguez Mediano, F., 2002, Pidal, Gómez-Moreno, Asin. Humanismo y progreso. Romances, monumentos $y$ arabismo, Madrid: Nivola.

Salvatierra Cuenca, V., 2013, «La primera arqueología medieval española. Análisis de un proceso frustrado (1844-1925)», Studia Historica. Historia medieval 31, 183-210.

Schnapp, A., 2002, "Between antiquarians and archaeologists - continuities and ruptures», Antiquity (special section: "Ancestral Archives. Explorations in the History of Archaeology») 76, 134-140.

Simonet, F. J., 1897-1903, Historia de los mozárabes de España. Madrid: Viuda e hijos de M. Tello.

Torres Balbás, L., 1936, «Los modillones de lóbulos. Ensayo de análisis de la evolución de una forma arquitectónica a través de diez y seis siglos», Archivo Español de Arte y Arqueología 12 (34), 1-62.

Utrero, M. de la Á., 2005, Iglesias tardoantiguas y altomedievales en la Península Ibérica: análisis arqueológico y sistemas de abovedamiento, Madrid: Consejo Superior de Investigaciones Científicas.

VARELA, J., 1999, La novela de España. Los intelectuales y el problema español, Madrid: Taurus.

VegA, J., 2016, "La Historia del Arte y su devenir en España. Circunstancias y reflexiones desde la práctica subjetiva», en: A. Molina Martín (ed.), La Historia del Arte en España. Devenir, discursos y propuestas, Madrid: Polifemo, 23-175.

Vílchez Vílchez, C., 1999, Leopoldo Torres Balbás, Granada: Comares. 